\title{
Article
}

\section{The Fairness Project: the role of legal educators as catalysts for change. Engaging in difficult dialogues on the impact of diversity barriers to entry and progression in the legal profession}

Mckee, Tina, Nir, Rachel Anne, Alexander, Jill, Griffiths, Elisabeth, Dargue, Paul and Hervey, Tamara

Available at http://clok.uclan.ac.uk/34505/

Mckee, Tina ORCID: 0000-0003-2011-6927, Nir, Rachel Anne, Alexander, Jill, Griffiths, Elisabeth, Dargue, Paul and Hervey, Tamara (2020) The Fairness Project: the role of legal educators as catalysts for change. Engaging in difficult dialogues on the impact of diversity barriers to entry and progression in the legal profession. The Law Teacher, 55 (3). pp. 283-313. ISSN 0306-9400

It is advisable to refer to the publisher's version if you intend to cite from the work. http://dx.doi.org/10.1080/03069400.2020.1796061

For more information about UCLan's research in this area go to http://www.uclan.ac.uk/researchgroups/ and search for <name of research Group>.

For information about Research generally at UCLan please go to http://www.uclan.ac.uk/research/

All outputs in CLoK are protected by Intellectual Property Rights law, including Copyright law. Copyright, IPR and Moral Rights for the works on this site are retained by the individual authors and/or other copyright owners. Terms and conditions for use of this material are defined in the policies page. 
The Fairness Project: The Role of Legal Educators as Catalysts for Change. Engaging in difficult dialogues on the impact of diversity barriers to entry and progression in the legal profession.

Tina McKee, ${ }^{\mathrm{a}}$ Rachel Anne Nir, ${ }^{\mathrm{a}}$ Jill Alexander, ${ }^{\mathrm{b}}$ Elisabeth Griffiths, ${ }^{\mathrm{b}}$ Paul Dargue, ${ }^{\mathrm{b}}$ Tamara Hervey. ${ }^{\mathrm{c}}$

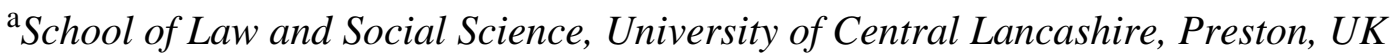

${ }^{\mathrm{b}}$ Northumbria Law School, Northumbria University, Newcastle upon Tyne, UK

${ }^{c}$ School of Law, The University of Sheffield, Sheffield, UK

Corresponding author: Elisabeth Griffiths, Northumbria Law School, Northumbria University, Newcastle upon Tyne, NE1 8ST. elisabeth.griffiths@ northumbria.ac.uk. 


\title{
The Fairness Project: The Role of Legal Educators as Catalysts for Change. Engaging in difficult dialogues on the impact of diversity barriers to entry and progression in the legal profession.
}

\begin{abstract}
This article provides a critique of The Fairness Project, a learning and teaching project on equality and diversity in the legal profession and its impact on employability, delivered over three years across three university law schools. The Fairness Project builds on current literature on lack of equality and diversity in the legal profession, by adopting a student perspective. Barriers to entry and progression within the legal profession occur because of a range of issues including social class, gender, ethnicity, initial education, university education and gaining work experience in a law firm. We explore whether, and to what extent, we can educate law students from a range of diverse backgrounds and social identities about the 'diversity barriers' entrenched in the legal profession, and thus influence their own career trajectories to access the profession. Our results show that - at least to some extent - we can. The data suggests that The Fairness Project helped prepare law students to tackle the inequalities that exist in the legal profession. The learning benefits of The Fairness Project are transferable to other law schools and could be adapted for use with law students in other jurisdictions, or for students in other disciplines where 'diversity barriers' may exist.
\end{abstract}

Keywords: equality and diversity; legal education; legal profession, employability.

\section{Introduction and Motivation for the Project}

Despite the massification of higher education producing a dramatic increase in the diversity of law students, the legal profession, in common with other professions, does not represent the diverse society it serves and remains one of the most elite professions 
in the UK. ${ }^{1}$ The Social Mobility Commission reported in April $2019^{2}$ that the better off are still 80 per cent more likely to make it into professional positions than those from working class backgrounds. This is notwithstanding pressure from the professional regulators and other bodies urging progress. ${ }^{3}$ Patterns of inequity and discrimination have

${ }^{1}$ The recent report of the Sutton Trust and the Social Mobility Commission states that: "Senior judges are the most socially exclusive groups of all the professions examined here, with the highest numbers of both independent school and Oxbridge alumni.": The Sutton Trust and the Social Mobility Commission, 'Elitist Britain 2019: The Educational Backgrounds of Britain's Leading People' (OGL, 2019) 55 <https://www.suttontrust.com/wp-content/uploads/2019/06/Elitist-Britain-2019.pdf> accessed 27 June 2019.

${ }^{2}$ The Social Mobility Commission, 'State of the Nation 2018-19: Social Mobility in Great Britain' (OGL

<https://assets.publishing.service.gov.uk/government/uploads/system/uploads/attachment_data/file/7 98404/SMC State of the Nation Report 2018-19.pdf> accessed 27 June 2019.

${ }^{3}$ See: Judicial Diversity Taskforce, 'Improving Judicial Diversity: Progress towards delivery of the "Report of the Advisory Panel on Judicial Diversity 2010", <https://assets.publishing.service.gov.uk/government/uploads/system/uploads/attachment_data/file/2 17326/judicial-diversity-taskforce-annual-report-2012.pdf> accessed 27 June 2019; Legal Services Board, 'Encouraging a Diverse Workforce: LSB Decision Document on Changes to Statutory Guidance for Regulators Issued Under Section 162 of the Legal Services Act 2007' (2017) <https://www.legalservicesboard.org.uk/what_we_do/consultations/closed/pdf/20170215/2017_Enco uraging_A_Diverse_Workforce.pdf> accessed 27 June 2019; Solicitors Regulation Authority, 'Unlocking the Benefits of Diversity' (2017) <https://www.sra.org.uk/sra/how-wework/reports/unlocking-benefits-diversity.page> accessed 27 June 2019; The Bar Standards Board has identified that "the Bar remains unrepresentative of the population that it serves in relation to several protected characteristics" and see this as one of their three most significant risk themes: Bar Standards Board, 'Risk Outlook' (2019) 5 https://www.barstandardsboard.org.uk/uploads/assets/008c77d1-fed74ee3-a1458960d1d40dc7/bsbriskoutlook2019.pdf> accessed 28 October 2019. In addition, the Solicitors Regulation Authority and the Bar Standards Board both have principles of equality and diversity integrated into the core of their Codes of Conduct. See Principle 9 and Chapter 2 of the SRA Code of Conduct (in both the old version (20) and the revised version (21) of the Code which came into effect on 25 November 2019): Solicitors Regulation Authority, 'SRA Code of Conduct 2011' (Version 21, 2018) < https://www.sra.org.uk/solicitors/handbook/code/part2/content.page> accessed 
been widely researched and reported over many years and the issues are now well rehearsed, ${ }^{4}$ including within student textbooks on the English legal system. ${ }^{5}$ Despite this acknowledged problem, the authors' experiences within their own law schools were that these issues were not explicitly discussed within the context of how law schools could influence a student's future employability. ${ }^{6}$ As a group of academics in three quite

27 June 2019; Rule c110-c112 and associated guidance in: Bar Standards Board, 'The Bar Standards Board Handbook' (Version 4.3, October 2019) <https://www.barstandardsboard.org.uk/uploads/assets/de77ead9-9400-4c9dbef91353ca9e5345/02f5d673-9982-4465-94d7e198aecb1e64/second-editiontest31072019104713.pdf> accessed 28 October 2019.

${ }^{4}$ Heather Rolfe and Tracy Anderson, 'A Firm Choice: Law Firms' Preferences in the Recruitment of Trainee Solicitors' (2003) 10(3) International Journal of the Legal Profession 315; Rosaline Sutherland, 'Barriers to the Legal Profession' (Legal Services Board, 2010) <https://www.legalservicesboard.org.uk/wp-content/media/2010-Diversity-literature-review.pdf> accessed 27 June 2019; Hilary Sommerlad and others, 'Diversity in the Legal Profession in England and Wales: A Qualitative Study of Barriers and Individual Choices' (Legal Services Board, 2010) $<$ http://www.legalservicesboard.org.uk/what_we_do/Research/Publications/pdf/lsb_diversity_in_the_ legal_profession_final_rev.pdf>, accessed 27 June 2019; Wolfgang Lehmann, 'Extra-credential Experiences and Social Closure: Working Class Students at University' (2012) 38(2) British Educational Research Journal 203; Louise Ashley and Laura Empson, 'Differentiation and Discrimination: Understanding Social Class and Social Exclusion in Leading Law Firms' (2013) 66(2) Human Relations 219; Eleanor Rowan and Steven Vaughan "“Fitting in" and "opting out": exploring how law students self-select law firm employers' (2018) 52(2) The Law Teacher 216.

5 See, e.g., Geoffrey Rivlin, Understanding the Law (6 $6^{\text {th }}$ edn, OUP 2012), chapter 7; Tom Frost, Rebecca Huxley-Binns and Jacqueline Martin, Unlocking the English Legal System $\left(6^{\text {th }}\right.$ edn, Routledge 2019), chapter 13; David Kelly, Slapper and Kelly's The English Legal System $\left(19^{\text {th }}\right.$ edn, Routledge 2020), chapter 12 and to some extent chapter 16; Steve Wilson and others, English Legal System, (4 ${ }^{\text {th }}$ edn, OUP 2020), chapter 8.

${ }^{6}$ The concept of employability has had considerable academic attention, with Morley describing it as "non-transparent and subjective" and providing "ideal preconditions for the reproduction of elitism and inequalities": Louise Morley, 'Employability, Equity and Elite Formation' (2011) 8 Higher Education Forum 75, 79. The introduction of the Teaching Excellence Framework ensures Universities engage with the employability agenda as the government monitors and assesses the quality of teaching in 
different law schools, ${ }^{7}$ we set out to develop a learning and teaching project with the purpose of educating students from diverse backgrounds about the "diversity barriers"8 to entry into (and progression within) the legal profession in an attempt to influence their career trajectories whilst at university. While raising diversity and inequality issues can be unsettling and uncomfortable for staff and students alike, ${ }^{9}$ the authors believe that remaining silent only adds a further layer of inequity to an already unfair system. The challenge was to offer law students a reality check without crushing their individual hopes and aspirations, and to manage this without undermining their confidence, which plays such a crucial role in constructing employability. ${ }^{10}$ The Fairness Project evolved from these concerns and seeks to offer a teaching and learning intervention to address the issues raised. ${ }^{11}$

England's universities, with one of the aims being to ensure all students receive an excellent teaching experience that encourages original thinking, drives up engagement and prepares them for the world of work.

${ }^{7}$ School of Law and Social Science, University of Central Lancashire (UCLan), Northumbria Law School, Northumbria University and School of Law, University of Sheffield.

8 "Diversity barriers" will be used in this article to mean barriers in the workplace that operate to discriminate against people based on differences in protected characteristics such as sex, race, ethnicity, disability, sexual orientation and also the inequalities of outcome which result from socio-economic disadvantage.

${ }^{9}$ Referred to in the literature as "difficult dialogues" because they "bring awareness to conflicting world views, evoke an emotional response, expose biases, and present the threat of being challenged in public": Derald Wing Sue and others, 'How White Faculty Perceive and React to Difficult Dialogues on Race: Implications for Education and Training' (2009) 37(8) The Counseling Psychologist 1090.

${ }^{10}$ Lorraine Dacre Pool and Peter Sewell, 'The Key to Employability: Developing a Practical Model of Graduate Employability' (2007) 49(4) Education and Training 277, 286.

${ }^{11}$ Francis and Sommerlad referred to curriculum development as a means of equipping "nontraditional" students with the information needed to enter and succeed in the legal profession: Andrew Francis and Hilary Sommerlad, 'Access to legal work experience and its role in the (re)production of legal professional identity' (2009) 16(1) International Journal of the Legal Profession 63, 65. 
The Fairness Project originated in the School of Law and Social Science, UCLan, in 2015 where Nir and McKee shared concerns regarding structural diversity barriers within the legal profession; and the effect of this on the career prospects of the very diverse cohorts of law students that they were teaching. They observed that many of their law students lacked any awareness of these barriers and naively imagined that a law degree would be the first step along a straightforward route to qualification and then practice within the legal profession as either a solicitor or barrister. This view is understandable given the way law schools market their programmes within a very competitive environment, ${ }^{12}$ the key focus being on the vocational aspects of legal education. ${ }^{13}$ Yet many of their students did not have the social capital ${ }^{14}$ or real-world

${ }^{12}$ For broader reflection on the ways in which universities intersect with the broader economies within which they are situated, see, e.g., Stefan Collini, What are Universities for? (Penguin 2012); Les Back, Academic Diary; Or Why Higher Education Still Matters (Goldsmiths Press 2016); Stefan Collini, Speaking of Universities (Verso 2017); Frank Furedi, What's Happened to the University? A Sociological exploration of its infantilisation (Routledge 2017); David Willetts, A University Education (OUP 2017).

${ }^{13}$ Margaret Thornton and Lucinda Shannon, "'Selling the Dream": Law School Branding and the Illusion of Choice' (2013) 23 Legal Education Review 249, 259; Margaret Thornton, 'Legal Education in the Corporate University' (2014) 10 Annual Review of Law and Social Science 19; Aysha Divan and others, 'Marketing graduate employability: understanding the tensions between institutional practice and external messaging' (2019) 41(5) Journal of Higher Education Policy and Management 485 . This vocational focus is contrary to those that view legal education from a liberal perspective, for example see Anthony Bradney, Conversations, Choices and Chances: The Liberal Law School in the Twenty-First Century (Hart Publishing 2003); Sherman J. Clark, 'Law School as Liberal Education' (2013) 63(2) Journal of Legal Education 235.

${ }^{14}$ Described by Pierre Bourdieu as "the aggregate of the actual or potential resources which are linked to possession of a durable network of more or less institutionalised relationships of mutual acquaintance and recognition - in other words, to membership in a group", Pierre Bourdieu, 'The Forms of Capital' in John Richardson (ed), Handbook of Theory and Research for the Sociology of 
awareness to understand the fiercely competitive nature of the legal jobs market to which they were aspiring, or to understand the deep-rooted elitism of the profession. ${ }^{15}$ Within this broader context of unfairness, Nir and McKee felt obliged to develop a learning and teaching equality and diversity project to develop student awareness of, and skills and strategies for, navigating any diversity barriers that the students might face in possible future legal careers. The project recognises that employability goes beyond a collection of skills and attributes and as Tomlinson argues, "employability must be seen as a socially active process by the way graduates position themselves and are positioned". ${ }^{16}$ While students are responsible for constructing their own employability, it is important for them to appreciate the wider context and the structural constraints some of them may face. ${ }^{17}$

The first Fairness Project learning sessions took place in UCLan in 2015-16. Following initial presentations of the project at conferences, ${ }^{18}$ Griffiths and Alexander from Northumbria Law School, Northumbria University and then Hervey from the School of Law at the University of Sheffield came on board in 2016, adapting the teaching and learning materials for use in their own universities. The Fairness Project ran in

Capital (Greenwood Press 1986) 248. The advantage of personal contacts is discussed in Rolfe and Anderson (n 4) 319.

${ }^{15}$ Fully discussed by Sommerlad and others, 'Diversity in the Legal Profession in England and Wales: A Qualitative Study of Barriers and Individual Choices' (n 4).

${ }^{16}$ Michael Tomlinson, 'Investing in the self: structure, agency and identity in graduates' employability' (2010) 4(2) Education, Knowledge and Economy 73, 74.

${ }^{17}$ Andrew Francis talks of the challenge being to "develop critical readings of employability for our students and acknowledge the structural constraints in which opportunities are seized and lost": Andrew Francis, 'Legal Education, Social Mobility and Employability: Possible Selves, Curriculum Intervention and the Role of Legal Work Experience' (2015) 42(2) Journal of Law \& Society 173, 201. ${ }^{18}$ Association of Law Teachers Annual Conference, Northumbria University, (Newcastle upon Tyne, April 2016); LERN Conference: 'How do we research and teach equality and diversity in legal education settings', Sheffield University, (Sheffield, September 2016). 
different years of the degree in the three universities. ${ }^{19}$ This was through circumstance rather than design, dictated by the parts of the curriculum in which the authors respectively had leverage to embed the learning sessions in their own universities. Although not part of the original project design, it gave us the opportunity to test whether there was any differential in impact according to year of study, but surprisingly this was not found to be the case.

The objectives of The Fairness Project are threefold: firstly, to raise student awareness of the structural and entrenched diversity barriers existing within the legal profession and to recognise the barriers to which students as individuals may be susceptible; secondly, to help students to develop strategies, tailored to their own needs, to find possible ways through such structural barriers; and thirdly, to raise awareness of, and to challenge, any biases that the students have themselves. The final objective was designed with the aspiration that this would encourage students to become more committed and better equipped to make fairer decisions in the future, should they progress to roles such as partners or managers in law firms where they might be responsible for recruitment and progression decisions themselves. The learning and teaching materials were designed to support these three objectives and are predominantly interactive, incorporating research tasks, discussion, and role-play, together with space for individual reflection and for tailored responses to career planning.

This paper evaluates the success of this teaching and learning intervention (which ran over a three year period and used the same questionnaire with a new cohort in each year of the project), and reflects on whether, and to what extent, we can teach students about equality and diversity issues in the legal profession and influence the way they

${ }^{19}$ Year 1 in Northumbria, year 2 in Sheffield and year 3 in UCLan. 
navigate entry into the profession. At the same time, this paper contributes to the literature on the diversity or otherwise of the legal profession. We contend that, through the development of an evidence-based model of good practice, there are wider implications for legal education and practice in other law schools. We believe that no real progress towards equality can take place unless we educate law students about these issues so that those who are advantaged can understand why, and those who are not can seek to find a way through the system from within, using their own constructive strategies for entry and progression, so far as is possible within the structural constraints. With social mobility now stagnating, ${ }^{20}$ it should be a priority for all universities to enable students from less privileged backgrounds to access careers and navigate into professions that are often de facto closed to them. ${ }^{21}$

\section{The Legal Profession: equality and diversity}

In terms of fair recruitment and progression of individuals with "protected characteristics" as defined in the Equality Act 2010, the legal profession falls short. There is a higher percentage of women than men at entry level into the profession, either as solicitors or as barristers. ${ }^{22}$ However, the progression of women into levels of seniority

${ }^{20}$ The Social Mobility Commission, 'State of the Nation 2018-19' (n 2) on page v reported that social mobility has stagnated over the last four years at virtually all stages from birth to work.

${ }^{21}$ Recruitment processes into elite firms enact forms of closure that restrict access to graduates from particular socio-economic backgrounds, see Ashley and Empson, 'Differentiation and Discrimination: Understanding Social Class and Social Exclusion in Leading Law Firms' (n 4) 221.

22 Bar Standards Board ('BSB'), 'Diversity at the Bar 2019' (2019) <https://www.barstandardsboard.org.uk/uploads/assets/912f7278-48fc-46df893503eb729598b8/Diversity-at-the-Bar-2019.pdf> accessed 27 March 2020; Solicitors Regulation Authority ('SRA'), 'How diverse is the legal profession?' (SRA, 20 March 2020) 
(e.g. partners in law firms or Queen's Counsel) is compromised ${ }^{23}$ and there is a recognised gender pay gap in the UK that is higher than in many other professions. ${ }^{24}$ In terms of ethnicity, the data is more complex, but still a cause for concern. Although, there is a greater representation of solicitors from black, Asian and minority ethnic (BAME) backgrounds within the profession than there is within the general population, much of the concentration of BAME solicitors is within sole partnerships or smaller firms and there is clear under-representation at senior levels within the bigger firms. ${ }^{25}$ Moreover, there is only limited movement towards more transparency with respect to the ethnicity pay gap. ${ }^{26}$ There appear to be similar progression challenges for BAME barristers with a significant drop in BAME representation among Queen's Counsel. ${ }^{27}$ Data on other protected characteristics is less reliable due to low response rates and smaller populations

$<$ https://www.sra.org.uk/sra/equality-diversity/key-findings/diverse-legal-profession/> accessed 22 March 2020.

${ }^{23}$ ibid.

${ }^{24}$ The Law Society and the Solicitors Regulation Authority, 'The Law Society Group 2018 Gender Pay Gap Report' (2018) <https://www.lawsociety.org.uk/about-us/the-law-society-group-gender-pay-gapreport/> accessed 27 June 2019; Tabby Kinder and Gurpreet Narwan, 'Gender pay gap widens at law firms', The Times (8 April 2019) <https://www.thetimes.co.uk/article/gender-pay-gap-widens-at-lawfirms-7kmrrwvmf $>$ accessed 27 June 2019.

${ }^{25}$ SRA, 'How diverse is the legal profession?' (n 22). BAME, is referenced in this article as it is the term used in reports within the legal profession and is a term widely referred to within government departments, public bodies and other similar bodies. However, the authors wish to acknowledge that BAME, and other similar terms, are contested terms and their use is widely debated. We appreciate that there is no single term that is universally accepted.

${ }^{26}$ Although there is generic data recently published with respect to the ethnicity pay gap (see Office for National Statistics, 'Ethnicity pay gaps in Great Britain: 2018' (2019) $<$ https://www.ons.gov.uk/employmentandlabourmarket/peopleinwork/earningsandworkinghours/artic les/ethnicitypaygapsingreatbritain/2018> accessed 9 October 2019), there needs to be more nuanced data made available with respect to the legal professions.

${ }^{27}$ BSB, 'Diversity at the Bar 2019' (n 22). 
with respect to some of the characteristics. Nevertheless, the available data still suggests gaps in fair representation. ${ }^{28}$ One of the most significant diversity barriers within the legal profession falls outside the scope of the protected characteristics listed in the Equality Act 2010: inequalities of outcome resulting from socio-economic disadvantage. ${ }^{29}$ Much of the upper strata of the profession is dominated by the privately educated, many of whom are graduates of Russell Group Universities, particularly Oxford and Cambridge. ${ }^{30}$ Such graduates are more likely than others to have high social capital, giving them greater advantage when accessing career opportunities in the legal profession. ${ }^{31}$ When considering the broader pool of aspiring lawyers from all higher education backgrounds, the situation is often made more complex when their various identities intersect across a number of protected characteristics often combined with socio-economic disadvantage. ${ }^{32}$ Student experience at the intersection can be overlooked

${ }^{28}$ SRA, 'How diverse is the legal profession?' (n 22); BSB, 'Diversity at the Bar 2019' (n 22).

${ }^{29}$ The public sector duty regarding socio-economic inequalities set out in Part 1 of the Equality Act 2010 has never been enacted.

${ }^{30}$ The SRA and the BSB use 'attendance at fee paying schools' and 'first generation in the family to attend university' as measures for social mobility in their data gathering from the professions: SRA, 'How diverse is the legal profession?' (n 22); BSB, 'Diversity at the Bar 2019' (n 22). See also: The Sutton Trust and the Social Mobility Commission, 'Elitist Britain 2019: The Educational Backgrounds of Britain's Leading People' (n 1).

${ }^{31}$ See: Louise Ashley and others, 'A Qualitative Evaluation of Non-Educational Barriers to the Elite Professions' (Social Mobility and Child Poverty Commission, 2015) <https://assets.publishing.service.gov.uk/government/uploads/system/uploads/attachment_data/file/4 34791/A qualitative evaluation of non-educational barriers to the elite professions.pdf $>$ accessed 27 June 2019; Francis, 'Legal Education, Social Mobility and Employability: Possible Selves, Curriculum Intervention and the Role of Legal Work Experience' (n 17).

32 "Intersectionality" is the term used to describe the way in which individuals may have more than one social identity that is subject to oppression and discrimination, and for such individuals, the effect of prejudice is multiplied. Intersectionality was first referred to by Kimberle Crenshaw, 'Demarginalizing 
and recruitment and progression decisions can be permeated not just by perceptions of race for example, but race combined with sex, combined with socio-economic status, combined with disability or sexuality and so on, adding layers of complexity and disadvantage.

The implications of the economic recession in $2008-2009^{33}$ left legal employers less willing to "take risks" and more likely to rely on their "tried and tested" measures for recruitment, leading to many employers targeting traditional entry routes from private education, through Russell Group Universities and Oxbridge. ${ }^{34}$ There is also a level of intransigence in some senior recruitment partners who justify their decisions based on the economic imperative and who have no appetite to adapt their working cultures to embrace diversity. ${ }^{35}$ To some extent, this is understandable when law schools in England and Wales produce far more law students each year than there are training contracts or pupillages available. ${ }^{36}$ The opportunities available for law graduates are changing with

the Intersection of Race and Sex: A Black Feminist Critique of Antidiscrimination Doctrine, Feminist Theory and Antiracist Politics' (1989) 1 University of Chicago Law Forum 139. See also the 2010 Legal Services Board ('LSB') Report, which examined inter alia how intersections of social categories affected people's career trajectories: Sommerlad and others, 'Diversity in the Legal Profession in England and Wales: A Qualitative Study of Barriers and Individual Choices' (n 4).

${ }^{33}$ Britain officially entered recession on 23 January 2009 when the Office for National Statistics reported that the economy had shrunk through the last two quarters of 2008.

${ }^{34}$ Ashley and others, 'A Qualitative Evaluation of Non-Educational Barriers to the Elite Professions' (n 31).

${ }^{35} \mathrm{ibid}$. Ashley and others describe the conflicting dynamics that elite law firms have between attracting talent while at the same time wanting to reduce risk and enhance image, suggesting that there is in fact no room for increased diversity based on social class. See also, Rolfe and Anderson (n 4).

36 The Law Society, 'Trends in the Solicitors' Profession Annual Statistics Report 2018' (The Law Society, 2019) <https://www.lawsociety.org.uk/support-services/research-trends/annual-statisticsreport-2018/> accessed 14 February 2020. BSB, 'Statistics about the Bar' (Bar Standards Board, 2019) $<$ https://www.barstandardsboard.org.uk/news-publications/research-and-statistics/statistics-about-the- 
fewer training contracts in comparison to the number of law graduates,${ }^{37}$ and more unpaid internships, low-paid paralegal and legal assistant type jobs. ${ }^{38}$ Many of these paralegal positions are situated within the "onshoring" sector of the profession, which Carroll and Vaughan describe as "legally lesser" and available to graduates from local, "good enough" law schools. ${ }^{39}$ Moreover, the drastic cuts to civil and criminal legal aid are being felt across the High Street sector, with the result that many of the law students that we teach, particularly those whose identities are diverse, will face disadvantage in accessing "quality" legal employment, irrespective of their individual merit and potential.

We acknowledge that it is too simplistic to state that the entirety of the profession is biased and that there is no progress. There is a growing recognition of unfair recruitment and progression practices and there are some initiatives designed to mitigate this unfairness - high profile examples include the Stephen Lawrence Scholarship scheme at Freshfields Bruckhaus Deringer ${ }^{40}$ and the increasing use of blind and contextual

bar.html> accessed 14 February 2020. This oversupply is not unique to England and Wales, the USA and Australia appear to be facing similar issues, see Herbert M Kritzer, 'It's the law schools, stupid! Explaining the continuing increase in the number of lawyers' (2012) 19 International Journal of the Legal Profession 20; Angela Melville, 'It is the worst time in living history to be a law graduate: or is it? Does Australia have too many graduates?' (2017) 51(2) TLT 203.

${ }^{37}$ The Law Society, 'Trends in the Solicitors' Profession Annual Statistics Report 2018' (n 36).

${ }^{38}$ Exact numbers of paralegals are not known but estimates vary from 60,000-300,000, see Chartered Institute of Legal Executives, 'Paralegals: The backbone of legal sector' (2017) <https://www.allaboutlaw.co.uk/law-careers/paralegal/paralegals-the-backbone-of-legal-sector> accessed 31 January 2020.

${ }^{39}$ Emily Carroll and Steven Vaughan, 'Matter Mills and London-Lite offices: exploring forms of the onshoring of legal services in an age of globalisation' (2019) 22(1-2) Legal Ethics 3, 4.

40 'Freshfields Stephen Lawrence Scholarship Scheme' (Freshfields Bruckhaus Deringer, Undated) $<$ https://www.freshfields.com/en-gb/about-

us/responsiblebusiness/freshfields stephen lawrence scholarship/> accessed 28 October 2019. In both Northumbria and UCLan's experiences of this scheme, the students who engaged with it found it 
recruitment strategies when screening applicants. ${ }^{41}$ There is also emerging evidence of the economic benefits to the legal profession of supporting inclusion and diversity within the workforce. ${ }^{42}$ Nonetheless, change is slow and the legal profession remains closed to, or at least difficult to access for, a large number of the students we teach in our law schools, particularly working class students ${ }^{43}$ and those studying at law schools in the post- 92 category. ${ }^{44}$

to be very valuable from a networking point of view albeit none of them progressed to a training contract.

${ }^{41}$ Blind and contextual recruitment has been endorsed by the Law Society, which produced guidance in 2016: The Law Society, 'Fair Recruitment Toolkit' (The Law Society, 2016) <https://www.lawsociety.org.uk/support-services/advice/articles/fair-recruitment-toolkit/> accessed 28 October 2019. Rare Recruitment offers a contextual recruitment system: 'Homepage' (Rare Recruitment, Undated) < https://www.rarerecruitment.co.uk/> accessed 28 October 2019. In addition, Rare Recruitment offers an online recruitment tool which Clifford Chance, Slaughter and May, Linklaters and Herbert Smith Freehills have adopted: Jemma Slingo, 'Top Firms Commit to Improve Social Diversity with Recruitment Tool', The Law Society Gazette (12 June 2019) <https://www.lawgazette.co.uk/news/top-firms-commit-to-improve-social-diversity-withrecruitment-tool-/5070584.article> accessed 27 June 2019.

42 SRA, 'The Business Case for Diversity' (2018) <https://www.sra.org.uk/risk/resources/riskbusiness-case-diversity.page $>$ accessed 27 June 2019; The Law Society, 'Diversity and Inclusion in Law Firms: The Business Case', (Undated) <https://www.lawsociety.org.uk/support-services/practicemanagement/diversity-inclusion/diversity-and-inclusion-in-law-firms-the-business-case/> accessed 28 June 2019; The Law Society, 'Diversity and Inclusion in Small Law Firms: The Business Case', (Undated) < Lhttps://www.lawsociety.org.uk/support-services/practice-management/diversityinclusion/diversity-and-inclusion-in-law-firms-the-business-case/> accessed 28 June 2019.

${ }^{43}$ Hilary Sommerlad, 'Researching and Theorizing the Process of Professional Identity Formation' (2007) 34 (2) Journal of Law and Society 190, 217.

${ }^{44}$ Andrew Francis refers to the importance placed by the largest recruiters on the institution attended and the further weakening of a student's social and cultural capital by the institution's reputational capital, Francis, 'Legal Education, Social Mobility and Employability: Possible Selves, Curriculum Intervention and the Role of Legal Work Experience' (n 17) 196. Large firms will typically focus their recruitment around a small number of elite universities, discussed in Hilary Sommerlad, 'The 
In our first article on The Fairness Project, ${ }^{45}$ we set out the background and motivation for the project, its aims and objectives, our student cohorts and the consequent pedagogic design of its learning materials. The nature of the project and our aspirations for its impact led to a careful design of the teaching materials to support the students' learning. We do not repeat at length here the detail of that earlier article. In brief, the design of the materials is informed by Bloom's ${ }^{46}$ classification (and developments thereof $)^{47}$ of learning objectives into the three domains: cognitive, affective and psychomotor, but is mainly positioned within the affective learning domain, which concerns feelings, attitudes, values and motivations. Students experience The Fairness Project as a series of learning activities with the same materials being used across all three law schools. Students use their research skills to answer questions set around the make-up of the legal profession. In doing this they begin to develop an awareness of the contextual landscape of the profession and their position in the market in which law graduates must compete for employment. Students then participate in a simulated recruitment exercise, into which we encoded, drawing on the extant literature, ${ }^{48}$ various

commercialisation of law and the enterprising legal practitioner: continuity and change' (2011) 18 International Journal of the Legal Profession 73, 80.

45 Tina McKee and others, 'The Fairness project: Doing What We Can, Where We Are' (2018) 5(1) Journal of International and Comparative Law 181.

${ }^{46}$ Benjamin S Bloom and others, Taxonomy of Educational Objectives: The Classification of Educational Goals (D. McKay, 1956).

${ }^{47}$ David R Krathwohl, Benjamin S Bloom, and Bertram B Masia, Taxonomy of Educational Objectives, The Classification of Educational Goals. Handbook II: Affective Domain (David McKay 1964) and see David R Krathwohl, ‘A Revision of Bloom's Taxonomy: An Overview' (2002) 41(4) Theory into Practice 212.

${ }^{48}$ Ashley and others, 'A Qualitative Evaluation of Non-Educational Barriers to the Elite Professions' (n 31); Ashley and Empson, 'Differentiation and Discrimination: Understanding Social Class and Social Exclusion in Leading Law Firms' (n 4); Sommerlad and others, 'Diversity in the Legal 
aspects of "merit" or "talent" as used by the legal profession in making recruitment decisions. Discussions also take place on potential strategies to navigate any diversity barriers, giving students access to market intelligence around contextualised recruitment processes, ${ }^{49}$ diversity schemes ${ }^{50}$ and raising their aspirations through positive role models. ${ }^{51}$ Students then reflect on what they have gained from the learning activities and begin to see how their own possible disadvantage(s) might play out in their career development. We acknowledge that each student will experience and respond to the various exercises differently, depending on their own place in the social order of recruitment to the legal profession. Most law students have access to a plethora of generic employability advice and guidance from within their own law schools and, more generally, from university careers services. We wanted to discover whether we could have some influence on an individual student's trajectory into the legal profession and guide their personal development through working alongside them to co-create constructive strategies to tackle any barriers they might experience, realistically and effectively. This

Profession in England and Wales: A Qualitative Study of Barriers and Individual Choices' (n 4); Sommerlad, 'The commercialisation of law and the enterprising legal practitioner: continuity and change' (n 44); Rolfe and Anderson (n 4); Hilary Sommerlad, 'The "Social Magic" of Merit: Diversity, Equity and Inclusion in the English and Welsh Legal Profession' (2015) 83 Fordham Law Review 2325 .

${ }^{49}$ For example, 'rare' Contextual Recruitment Services has over 40 law firms as clients, and in 2018 , $14 \%$ of trainee hires across 11 City law firms came from 'rare', <https://rarerecruitment.co.uk/index.php>, accessed 17 February 2020.

50 For example, Law Society Diversity Access Scheme, <http://www.lawsociety.org.uk/lawcareers/Becoming-a-solicitor/equality-and-diversity/diversity-access-scheme/>, accessed 17 February 2020; Aspiring Solicitors, <https://www.aspiringsolicitors.co.uk/, accessed 17 February 2020; Freshfields Stephen Lawrence Scholarship Scheme, <https://www.freshfields.com/en-gb/aboutus/responsible-business/freshfields_stephen_lawrence_scholarship/>, accessed 17 February 2020.

51 The Law Society, 'Social Mobility Ambassadors' <https://www.lawsociety.org.uk/lawcareers/equality-and-diversity/social-mobility-ambassadors/> accessed 17 February 2020. 
second article comments on the last phase of this learning and teaching project: the findings. We also reflect on the initial drivers and rationale for the project and the extent to which we have achieved our stated aim.

\section{Methodology and Design}

We were keen to explore whether we could educate students about equality and diversity in the legal profession if they had limited or no awareness at the start, and whether we could enable them to better understand the legal landscape many of them hoped to enter. ${ }^{52}$ To do that, we needed to gather our students' thoughts before and after the activities in order to measure any changes. There was no intention to produce statistically robust analysis of the data; hence, we deliberately did not test for statistical significance. We used a mixed methodology approach, consisting of a standard questionnaire used by all three universities and a focus group at UCLan. These formed the basis for the project.

With these aims in mind, we designed the questionnaires to capture the students' understanding and awareness of barriers, progression, and bias in the legal profession. The project took place over three academic years with three different cohorts, 2016-17, 2017-18, 2018-19. Each university involved in this project obtained ethical approval through their own ethics committees. Students were informed that taking part in the project was voluntary and anonymous and they were provided with information regarding

\footnotetext{
52 The majority of law students entering higher education envisage a professional career, see: Melissa Hardee, 'Career Expectations of Students on Qualifying Law Degrees in England and Wales: A Legal Education and Training Survey' (The Higher Education Academy, 2012); Melissa Hardee, 'Career Expectations of Students on Qualifying Law Degrees in England and Wales Interim report: Comparing the First Year of the Cohort Study in 2012-2013 with the UKCLE Study March 2012' (The Higher Education Academy, 2014).
} 
the use of the data in future research publications. They were also offered direction to sources of support as appropriate should the learning activities or surveys cause distress.

As we note, this project is largely a pedagogic exercise. In the following sections of the article, we recount all the questions we asked students and provide details as to how students answered pre and post-activity. We acknowledge certain limitations with the questionnaire design at the outset. It may be that the questions we asked were not as clear as they might have been, especially for pre-activity questionnaires. Although we believed the meaning of the questions were made clear by the context, and tutors did not report students having difficulties with the questionnaires, we recognise the importance of careful questionnaire design. ${ }^{53}$ If we were to redesign the questionnaires for future use, we would probably reconsider our use of questions regarding conscious and unconscious bias. Perhaps further explanation of some key terms, such as "barriers", in the pre-activity questionnaires would have been useful to extinguish any doubt.

This means that there must be an element of doubt / caution when we present our results. We cannot be sure that all students have understood all questions in the same way, and so their answers might not mean the same thing. For example, when we asked students pre-activity how aware they were of barriers, they may have thought they were aware, until the sessions uncovered barriers which they did not know about. Nevertheless, the aim of The Fairness Project started as a learning and teaching exercise and was not originally designed as a research project. Our questionnaires were adequate for those purposes, and provide some useful data on which we reflect here.

\footnotetext{
${ }^{53}$ See Norman M Bradburn, Seymour Sudman and Brian Wansink, Asking Questions: The Definitive Guide to Questionnaire Design - For Market Research, Political Polls, and Social and Health Questionnaires (2nd, revised edn, John Wiley \& Sons 2004).
} 
The core learning was the same across all three law schools, but the learning activities were delivered in slightly different ways at each university. We consider this could produce a limitation to the findings, as it may be that different methods of delivery could influence the students' responses to the questionnaires. At UCLan, the programme was delivered in the form of two small workshops (circa 12-16 students in each group) as an integrated part of a compulsory third year skills module. Similarly, at Northumbria, it was delivered in the form of small workshops (circa 16-18 students in each group), and was an integrated part of a compulsory first year employability module. In Sheffield, it was delivered to second year students beginning with individual-guided tasks. Meetings were then held in peer groups (circa 15-20 students in each group) for initial discussions, some feedback in a small-group personal tutorial (circa 7 students in each group) and finally meeting as a full year two cohort (circa 320-400 students) in a café-style workshop. Each university therefore delivered the learning materials to different year groups and to different students each year. This is a further potential limitation, as it might be thought that (particularly) students at later stages of their degree might have higher levels of awareness before the sessions.

We used supervised self-completion questionnaires to gather data rather than interviews as it meant a large amount of data could be collected in a quicker and more cost effective manner. ${ }^{54}$ It also offered consistency across the three universities as selfcompletion questionnaires avoid the problems associated with multiple interviewers who may vary the format or content of the questions. ${ }^{55}$ Questionnaires also offered the

\footnotetext{
54 Virginia Braun and Victoria Clarke, Successful Qualitative Research, a Practical Guide for Beginners (SAGE 2013) 137.

${ }^{55}$ Louis Cohen, Lawrence Manion, and Keith Morrison, Research Methods in Education (8 ${ }^{\text {th }}$ edn, Routledge 2018) 334-5.
} 
opportunity to gather data from students in absolute privacy and anonymity, which would lead to more genuine responses being given. Face-to-face interviews by academics with the imbalance in power could have meant students were providing responses that they "thought the academic wanted to hear" rather than being genuine responses. Closed questions were primarily asked and while this does lead to the enhancement of comparability and ease of processing, open questions were included when it was felt they were more appropriate. We asked personal factual questions to gather demographic data about the students and we asked questions about knowledge to "test" their awareness of diversity barriers within the legal profession. We also decided to ask questions about beliefs to see if we could ascertain understanding of conscious and unconscious bias amongst the student population.

Students who consented to taking part in this project completed a pre-activity questionnaire before they undertook the learning activities. Advice was given to staff who delivered the workshop as to the purpose of the research and how the research should be introduced to the students. Those same staff then supervised the completion of the questionnaire in the teaching session. The second questionnaire, the post-activity questionnaire, was completed after students had taken part in the learning activities.

In the early stages of the project, a focus group was held with twelve law students in their third year at UCLan. It took place approximately five months after the students had participated in The Fairness Project learning sessions. The focus group complied with the appropriate ethical requirements under the approval of the UCLan Research Ethics Committee and was facilitated by Nir and McKee. As The Fairness Project is first and foremost a teaching and learning intervention, it was important for the project team to gain insight into the student experience of the materials. The purpose of the focus group was therefore primarily to gauge students' responses to the intervention, rather than 
to provide comprehensive research data for full analysis. Focus groups can be a way of providing insights into how individuals perceive a situation, ${ }^{56}$ and are a recognised tool in educational contexts when assessing teaching materials ${ }^{57}$ Due to resource constraints, it was not possible to run focus groups in later years or across all three law schools or to develop a more robust focus group methodology. It is accepted that these limitations restrict the reliability of the focus group findings; we submit that nonetheless, they have some merit in facilitating "triangulation" with our survey findings $;{ }^{58}$ and in offering a more nuanced insight into the student experience. ${ }^{59}$

For the focus group, students were recruited from the pool of students who had participated in The Fairness Project workshop sessions. All eligible students were invited and all those who volunteered to participate were included. Despite this element of "self-selection", the resulting group was broadly representative of the wider cohort in terms of both gender and ethnicity. Questions were asked to evaluate the learning activities and to prompt deeper student reflection. This part of the research project was inductive and interpretive and drew out themes from the data collected. ${ }^{60}$

${ }^{56}$ Richard A Krueger, 'Quality control in focus group research' in David L Morgan (ed), Successful focus groups: advancing the state of the art (SAGE 1993).

${ }^{57}$ C Bryant and E Gulitz, 'Focus group discussions: an application to teaching' (1993) 24 Journal of Health Education 24; Javier Gilflores and Cristina Granado Alonso, 'Using focus groups in educational research: Exploring teachers' perspectives on educational change' (1995) 19(1) Evaluation Research 84,85 .

${ }^{58}$ Using a range of research methods can offer the opportunity to "triangulate" findings i.e. to test them against each other for substantiation. See Andrew Parker and Jonathan Tritter, 'Focus group method and methodology: current practice and recent debate' (2006) 29(1) International Journal of Research \& Method in Education 23, 25.

${ }^{59}$ ibid 34.

${ }^{60}$ John Dewey, How We Think: A Restatement of the Relation of Reflective Thinking to the Educative Process (D.C. Heath \& Co 1933). 
Throughout this project, we were cognisant of our "insider" status as lecturers undertaking research, using students as participants and were reflexive ${ }^{61}$ in our approach to analysing the data. There was recognition of potential bias from the "insider"62 positioning and we created a consciously reflexive ${ }^{63}$ environment that enabled us to consider the data through a critical lens.

\section{Findings}

\section{Part 1: Sample profile}

In this section, we will consider the questionnaires, as all three universities participated in this element of the project. We will then move to the findings of the focus group. The questionnaires for all three universities across the three academic years were coded into an SPSS dataset. Any questionnaires, which did not answer all seven questions, were discarded. All questionnaires were anonymous. There was no attempt to track whether any individual student had changed their answers after the activity; the aim was to explore changes across the whole cohort and between different groups. In total, over the three years there were 959 "pre-activity" questionnaires coded, and 726 "post-activity" questionnaires coded. This represents an attrition rate of $25 \%$ pre to post activity. It should

${ }^{61}$ Ann L Cunliffe, 'Reflexive Inquiry in Organizational Research: Questions and Possibilities' (2003) 56(8) Human Relations 983.

${ }^{62}$ Sonya Corbin Dwyer and Jennifer L Buckle, 'The Space Between: On Being an Insider-Outsider in Qualitative Research' (2009) 8(1) International Journal of Qualitative Methods 54; Brian Bourke, 'Positionality: Reflecting on the Research Process' (2014) 19(33) The Qualitative Report 1; Elizabeth McNess, Lore Arthur and Michael Crossley, "Ethnographic Dazzle" and the Construction of the "Other": Revisiting Dimensions of Insider and Outsider Research for International and Comparative Education' (2015) 45(2) Compare: A Journal of Comparative and International Education 295.

${ }^{63}$ Catherine Cassell, Ann L Cunliffe and Gina Grandy (eds), The Sage Handbook of Qualitative Business and Management Research Methods (SAGE 2017) Chapter 23. 
be noted that around 2500 students (over the three years) were timetabled to attend the sessions, which is considerably more than completed the questionnaires. This would indicate that some students either did not attend the classes at all or chose not to complete the questionnaires. Tutors did not report serious issues with students in attendance completing the questionnaires, except in the instance where the session over-ran, where the post-activity questionnaires were not completed; so, we assume, in general, that there were attendance issue. In the academic year 2016/17 there were 336 pre-activity questionnaires (35\% of total); 289 (30\%) in 2017/18; and 334 (35\%) in 2018/19. Postactivity these figures are 316 in 2016/17 (43\% of total); 190 in 2017/18 (26\%); and 220 in 2018/19 (30\%). In terms of each university, 507 (52\%) pre-activity questionnaires were from Northumbria, 174 (19\%) from UCLan, and 278 (29\%) were from Sheffield. Postactivity 377 (51\%) were from Northumbria, 137 (19\%) were from UCLan and $212(30 \%)$ were from Sheffield.

We asked students to provide some demographic details about themselves. One of the subsidiary aims of this project was to explore whether certain groups experience the activity differently, or obtain more benefit from it. In the interests of space, the figures provided below are taken from the pre-activity questionnaires and figures from postactivity questionnaires are not provided. In any event, since the post-activity questionnaires were a sub-set of students who completed the pre-activity questionnaires, the demographic details for the post-activity questionnaires were very similar to the preactivity questionnaires. Many of the demographic characteristics resulted in the return of small numbers. For instance, across the three universities, only 3\% (including those who selected "don't know" or "prefer not to say") said that they had a disability; and only $11 \%$ (including "prefer not to say") said they were anything other than heterosexual. We asked students to select their religion. Other than "not religious" (49\% of answers); "Christian" 
(32\%), and "Muslim" (11\%), only a handful of students selected "other religions". The gender split, similar across all three universities pre and post activity, was $70 \%$ female and $30 \%$ male.

In relation to ethnicity, $72 \%$ of students self-selected "white any" as an option. The next largest group was "Asian any" (14\%). The other options were again selected only on a handful of occasions. To seek to combat the small numbers, we combined the ethnic categories into a "BAME" category. Any student who selected a category other than white was re-coded as BAME: $26 \%$ were BAME. This provides a more robust variable for later analysis. We acknowledge that combining categories in this way loses some of the richness of the data. We also acknowledge that students did not choose to identify themselves as "BAME". Nevertheless, we felt ethnicity was an important factor to consider and this was a viable way of so doing. Northumbria, with $15 \%$, has the lowest proportion of BAME students; Sheffield had 33\% BAME; and UCLan 46\%.

We also asked students about their social and educational background. Overall, $70 \%$ of students across the three universities attended a non-selective free-to-attend state school, and $40 \%$ were the first in their family to go to university. Sheffield had the lowest proportion of state school students (still over half at 57\%; both Northumbria and UCLan were over $70 \%$ state educated). Sheffield had the highest proportion of privately educated $(21 \%)$ and grammar school educated (15\%) students.

We now turn to the answers students gave to the seven questions in the pre and post-activity questionnaires. We wanted to explore whether the objectives of the project had been met and whether certain groups attending the sessions felt they were more aware, or whether certain groups felt they obtained more benefit (or less) from the sessions. In this section we provide a comparative analysis of the overall answers to the pre-activity questionnaire with those in the post-activity questionnaire by looking at 
overall outcomes pre- and post- activity and also at cross tabulations between groups of students according to their demographic characteristics. We sought to understand not only overall outcomes but also how different groups of students answered the questions to see how far the sessions had affected them. We find there is some variation in how different students answered each question, and these are the ones we discuss in detail. If a particular variable is not discussed in this section this is because there was no difference in responses when that variable was considered. Due to rounding, some percentages in the figures or the narrative may not sum to exactly $100 \%$.

\section{Part 2: Overall outcomes pre-activity compared with post-activity.}

Question 1: How aware are you of possible diversity barriers to entry to the legal profession?

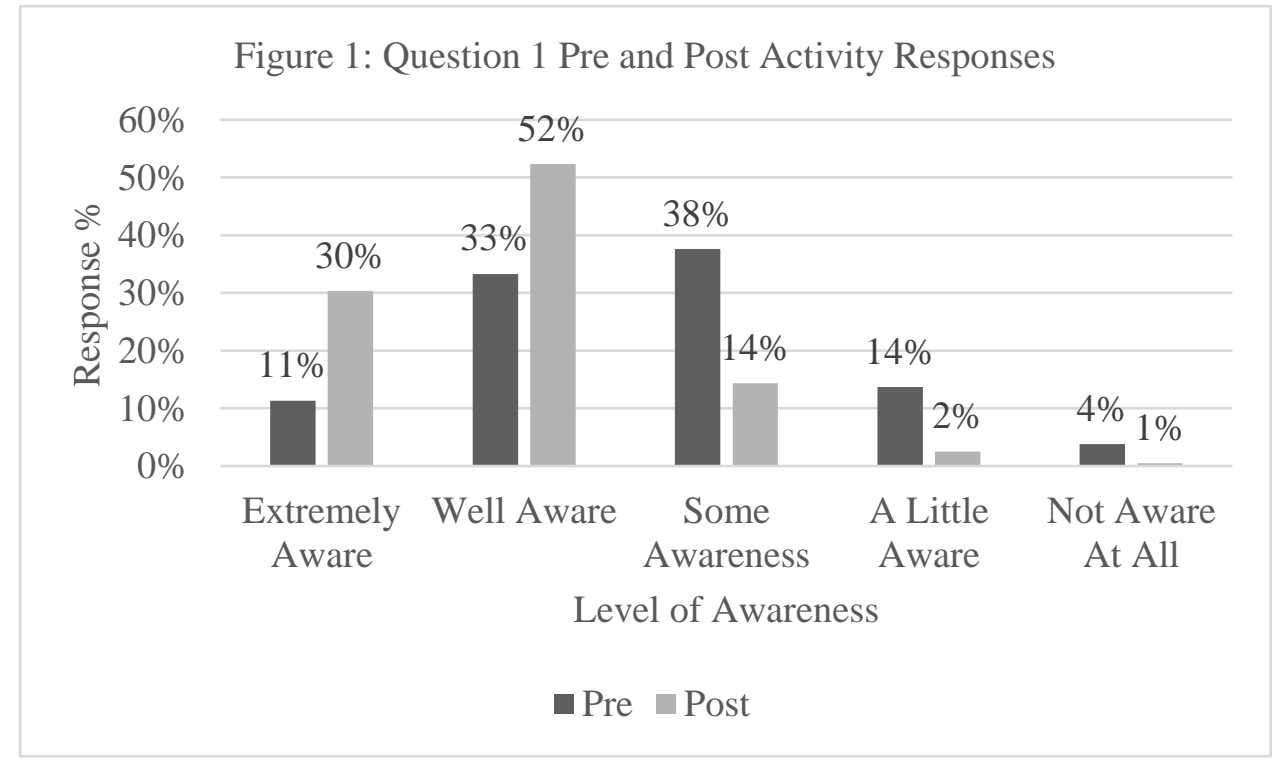

In Figure 1, before the sessions took place, some $44 \%$ of students answered that they felt that they were "extremely aware" or "well aware" of barriers to entry to the legal profession. There remained $56 \%$ of students who said they only had "some awareness", "a little awareness" or "not aware at all" of diversity barriers to entry. 
The post-activity responses demonstrate the session had a good impact in improving perceived awareness, $82 \%$ of students now reported as being "extremely aware" or "well aware". In question one, none of gender; religion; previous education; or whether the student was the first in their family to attend university showed any association with the answers provided either pre or post-activity. Due to low numbers, we did not analyse according to the variables of age; disability; or sexuality. We found that $16 \%$ of students attending Sheffield said they were "extremely aware" pre-activity, which is a greater proportion than at Northumbria and UCLan (9\% and $8 \%$ respectively). Postactivity, UCLan made the greatest gains in awareness (up to 38\%), while Sheffield increased to $31 \%$, and Northumbria somewhat further behind at $26 \%$. We also find that BAME students were much more likely to report themselves as "extremely aware" preactivity than white students (17\% and 9\% respectively; and 34\% of BAME students said "well aware" compared to $32 \%$ of white students). Post-session, BAME students were again more likely to report themselves as extremely aware (32\% against $28 \%$ ), $82 \%$ of BAME and white students overall said they were either extremely or well aware. 
Question 2: How aware are you of possible diversity barriers to progression within the legal profession?

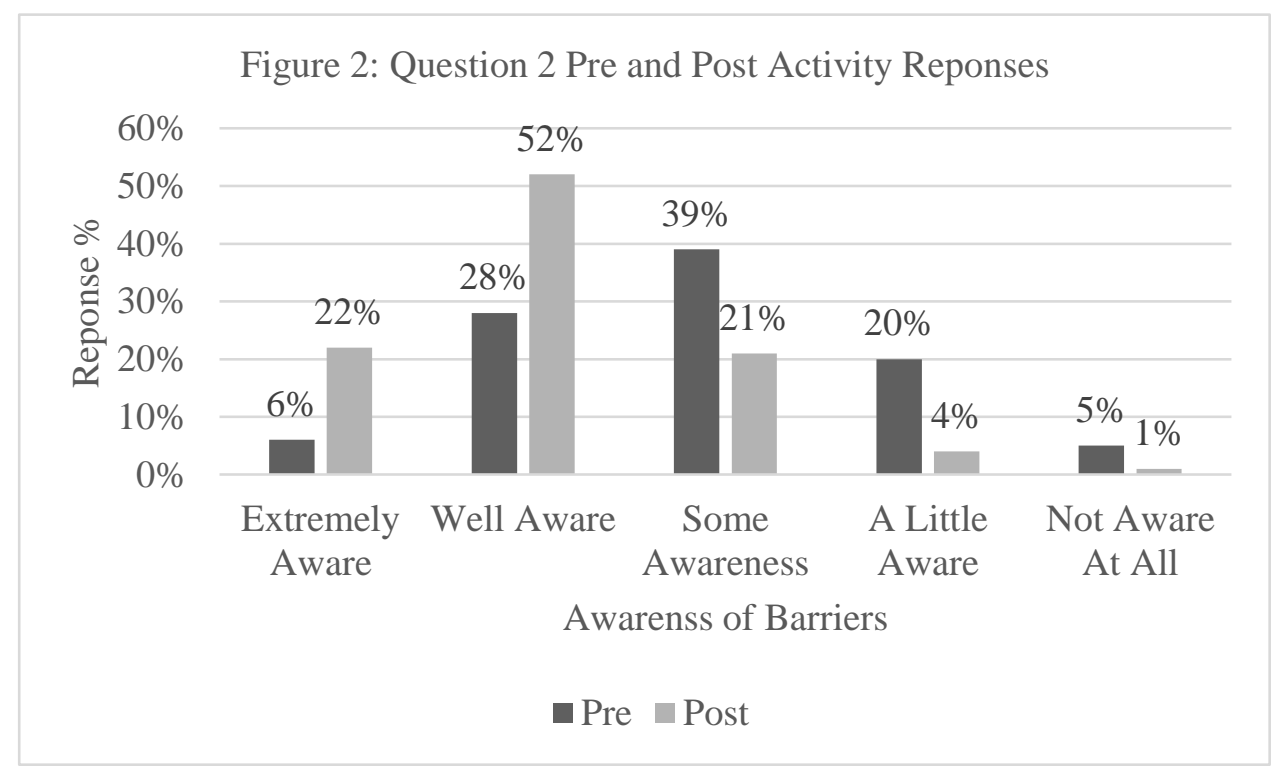

In Figure 2, fewer students (34\%) entered the sessions "extremely well" or "well aware" of progression barriers when compared to question one. Some $66 \%$ of students reported only "some awareness", "a little awareness" or were "not aware at all" of barriers to progression. It may be that students were not entirely clear on the meaning of the word "barriers".

The session had a positive impact on the students' self-reported knowledge, with 74\% reporting as being "extremely aware" or "well aware", a significant improvement on the pre-activity questionnaire. Only $5 \%$ of students remained only "a little aware", or "not aware at all". In relation to question two, there was little difference pre or postactivity between any of the groups of students. 
Question 3: To what extent do you feel equipped to navigate any such diversity barriers?

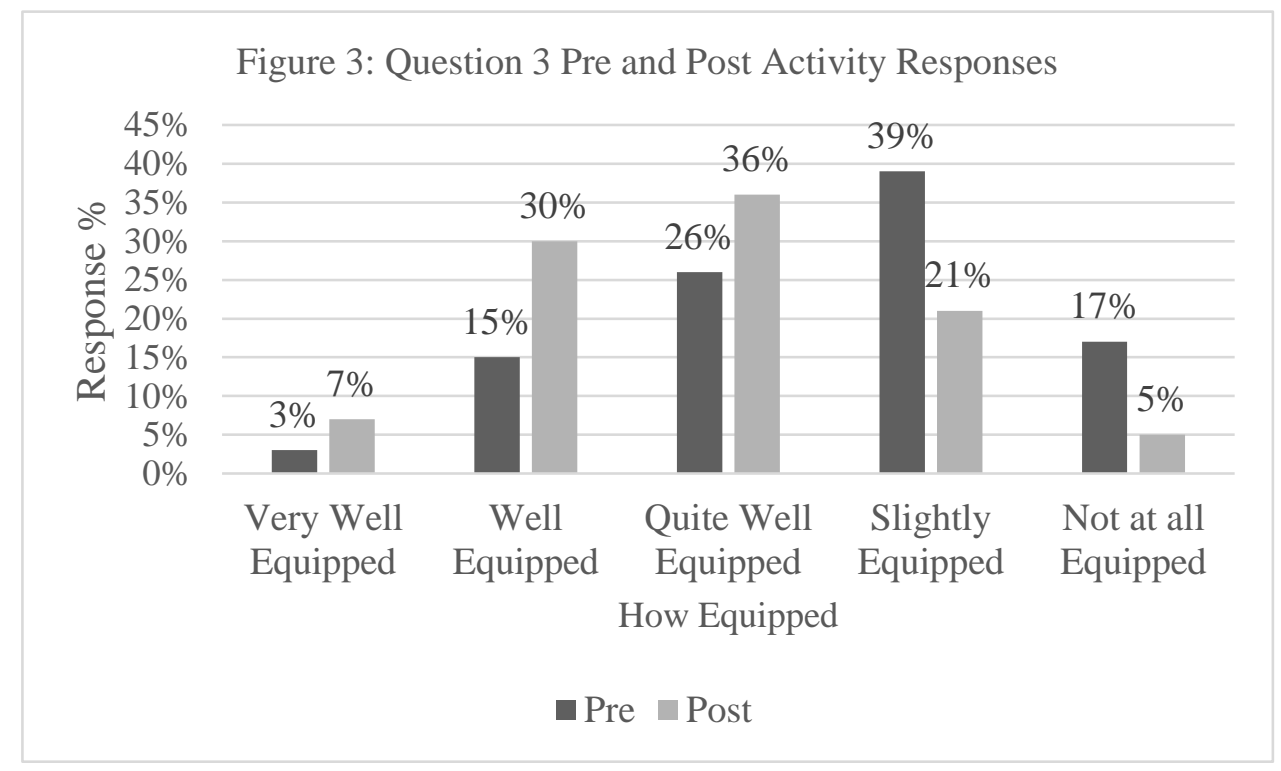

Figure 3 shows that pre-activity, 44\% of students felt "very well equipped", "well equipped" or "quite well equipped" to navigate diversity barriers, which is broadly consistent with responses to Question 1, where $44 \%$ of students answered that they were "extremely aware" or "well aware" of barriers to entry to the legal profession. $56 \%$ were "slightly equipped" or "not equipped at all". At first sight, this can seem quite surprising to some, but it has to be seen in context. The Northumbria students are in Year 1 when they engage with this project and so are just at the beginning of their exploration of career opportunities and at Sheffield and UCLan, the students are in Years 2 and 3 respectively, and some may have decided by that point not to pursue a career in law. ${ }^{64}$

${ }^{64}$ See: Melissa Hardee, 'The Cohort Study of the Career Expectations of Students on Qualifying Law Degrees in England and Wales' (2016).

$<$ https://ials.sas.ac.uk/sites/default/files/files/About\%20us/Leadership\%20\%26\%20Collaboration/LE

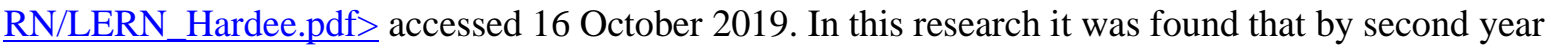
$55 \%$ of students had changed their minds about their career choices and $26 \%$ were no longer planning to pursue a career in law. 
Post-activity, there is a clear improvement in how equipped the students reported they felt, with now over $70 \%$ of students being at least "quite well equipped". On the other hand, $26 \%$ of students, a sizeable number of individual students, remained only "slightly equipped" or "not at all equipped". While this is a $30 \%$ reduction from the preactivity questionnaire, it does remain a challenge for us as educators. Perhaps because it is more difficult to navigate something than it is to be aware of the existence of something, for a significant proportion of students not all of the overall aims of the project were met. ${ }^{65}$ In relation to question three, male students were more likely to say they were either well equipped or very well equipped before the session than female students $(26 \%$ of male students answered this way, against $14 \%$ of female students). Post-activity, this difference remains: $44 \%$ of male students answered well or very well equipped, while only $34 \%$ of female students did. Students who attended a private fee-paying school were more likely to say they were well or very well equipped, compared to state school educated students (25\% and $16 \%$ of students respectively answered this way). Postactivity there is a reversal, with $33 \%$ of privately educated students and $38 \%$ of state educated students selecting well or very well equipped.

${ }^{65}$ In addition, some of the students might only have attended some rather than all of the learning activities. 
Question 4: To what extent do you have biases towards other groups of people on the basis of diversity factors?

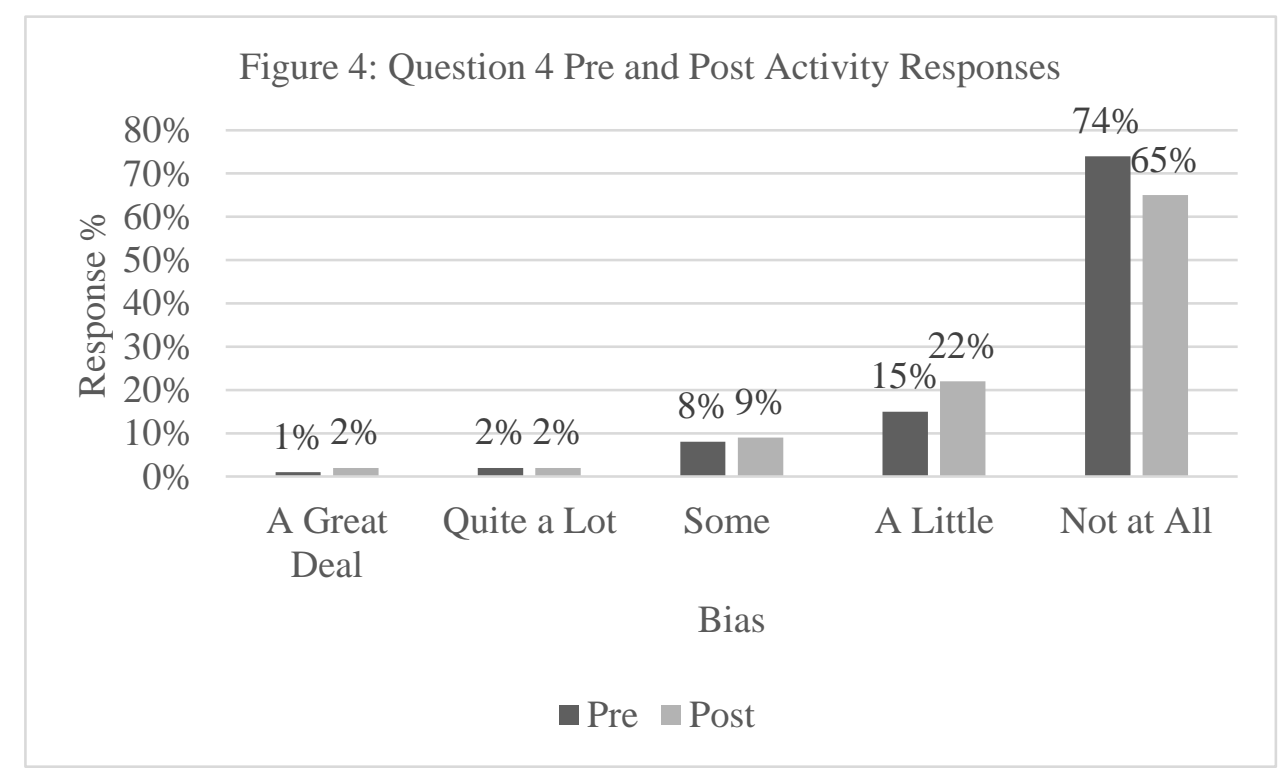

Figure 4 shows that in the pre-activity questionnaire, $74 \%$ of students reported that they did not have any biases, which is unsurprising since in modern society, it is generally unacceptable to behave in a prejudiced manner, ${ }^{66}$ and the "bias blind spot" suggests that people are unlikely to accept that they are biased, while acknowledging bias in others. ${ }^{67}$ Perhaps it is more surprising that $26 \%$ of students were prepared to state they held biases towards other groups.

Post activity, there is some movement with a 9\% reduction in those who said they had no biases at all, albeit they mainly appear to have shifted only into the "a little" 〈https://www.ecu.ac.uk/wp-content/uploads/2014/07/unconscious-bias-and-higher-education.pdf > accessed 24 October 2019. People can be motivated to say they have no biases in order to avoid social sanction or they can be motivated to do so due to their own beliefs and values: Patricia G Devine and others, 'The Regulation of Explicit and Implicit Race Bias: The Role of Motivations to Respond Without Prejudice' (2002) 82(5) Journal of Personality and Social Psychology 835.

${ }^{67}$ Emily Pronin, Daniel Y. Lin and Lee Ross, 'The Bias Blind Spot: Perceptions of Bias in Self Versus Others' (2002) 28(3) Personality and Social Psychology Bulletin 369. 
category. Pre-activity, female students were more likely than male students to answer "not at all" ( $78 \%$ of females and $65 \%$ of males answered this way). Male students were instead more likely to answer "a little" (20\% of males and $12 \%$ of females say "a little"). Post-activity, females remained more likely to answer "not at all" (67\%) than males (59\%), but more females were prepared to answer "some" (now 21\%). An interesting observation is that pre-activity students from private fee-paying schools were much less likely to answer "not at all" than their state school equivalents (55\% to $73 \%)$; suggesting they were more aware of their own biases than state school students. They were also more likely to select "a little" (24\% answered this way) or "some" (17\%) than state school students (12\% and 6\% respectively). Post-activity, both state school and privately educated were slightly more likely to admit to biases, private fee-paying school students remained more likely to do so than state school students. Pre-activity BAME students were also more likely than white students to select "some" (13\% and 5\% respectively) and less likely to select "not at all" (66\% to $78 \%$ respectively), and they remained more likely to accept their personal bias post-activity (although to a lesser degree). 
Question 5: How likely do you think it is that you have unconscious biases towards other groups of people on the basis of such diversity factors?

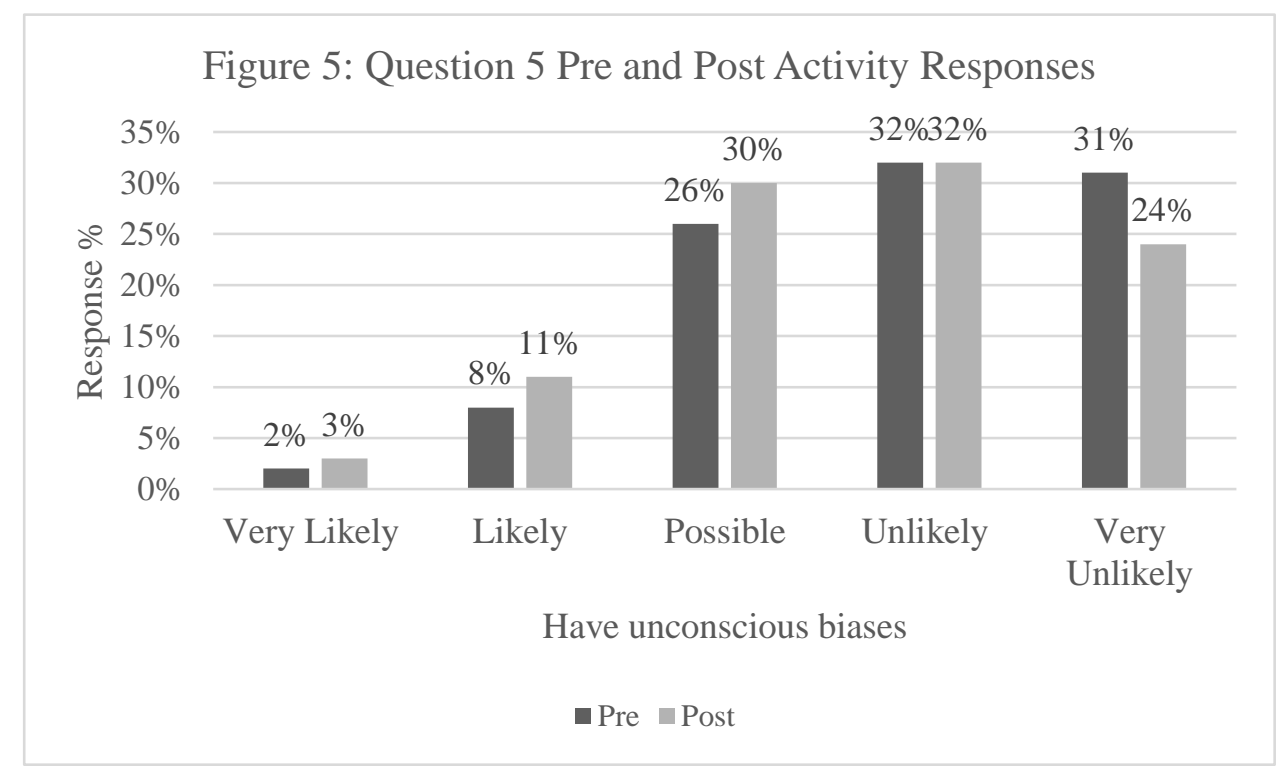

In Figure 5, students were more prepared to accept they might have unconscious bias than they were conscious bias. $36 \%$ of students though it at least possible; but only $10 \%$ thought it likely or very likely. Post-activity there is a shift in that slightly more students (now 44\%) thought it was possible they held unconscious bias. This is an improvement in terms of critical awareness of their own biases, but there remained $24 \%$ who thought it very unlikely they had even unconscious bias.

The findings for question 5 are similar to question 4: males, the privately educated, and BAME students were more likely to admit to unconscious bias, but the differences between students were narrower. For instance, pre-activity $27 \%$ of male students answered "not at all" while $33 \%$ of female students did; $30 \%$ of BAME students answered "not at all" while $32 \%$ of white students did. Post-activity, males, privately educated students, and BAME students remained more likely to admit to at least some unconscious bias, but only slightly. Overall, therefore, students answered the question regarding unconscious bias much more similarly pre- and post-activity than they did in question four, about bias in general. 
Question 6: To what extent do you think you have been affected by other people's biases in any part of your life?

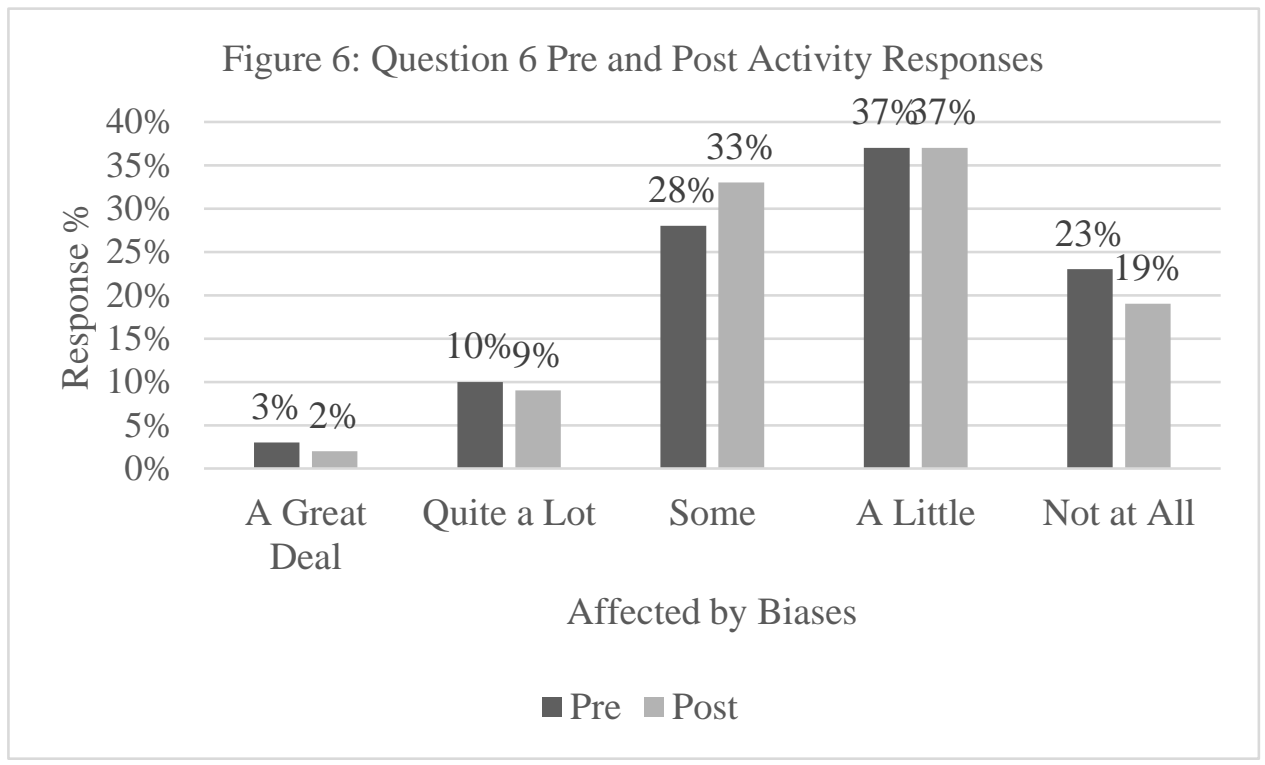

Pre-activity, only a minority of students (23\%) thought they had not been affected by bias at all themselves, while $65 \%$ thought they had been at least "some" or a "little" affected. It is noteworthy that most students think they have been affected by the bias of others, yet so few are prepared to admit having bias themselves, consciously or unconsciously, although this is explained by the "bias blind spot". ${ }^{68}$ As can be seen by figure 6 , there was little difference in the answers given pre and post-activity. Students were slightly less (now 19\%) likely to state they have been "not at all" affected by bias than they were before the project activities. This suggests a modest growing awareness of the realities of being affected by bias. The only characteristic factor which appeared related to the answer to this question is the BAME variable. Pre-activity BAME students were less likely than other students to answer "not at all" (12\% and $26 \%$ respectively), and were more likely to select either "some", "quite a lot" or "a great deal" (in total $62 \%$ of BAME students

${ }^{68}$ ibid. 
selected one of these options, while only $32 \%$ of white students did). Post-activity, both BAME and white students felt they were more likely to have been affected by bias, with BAME students remaining more likely to have selected at least "some" (60\% of BAME students now selected this, a slight reduction, and $41 \%$ of white students did so).

Question 7: How confident are you that you will treat people fairly if you become an employer or manager in the future?

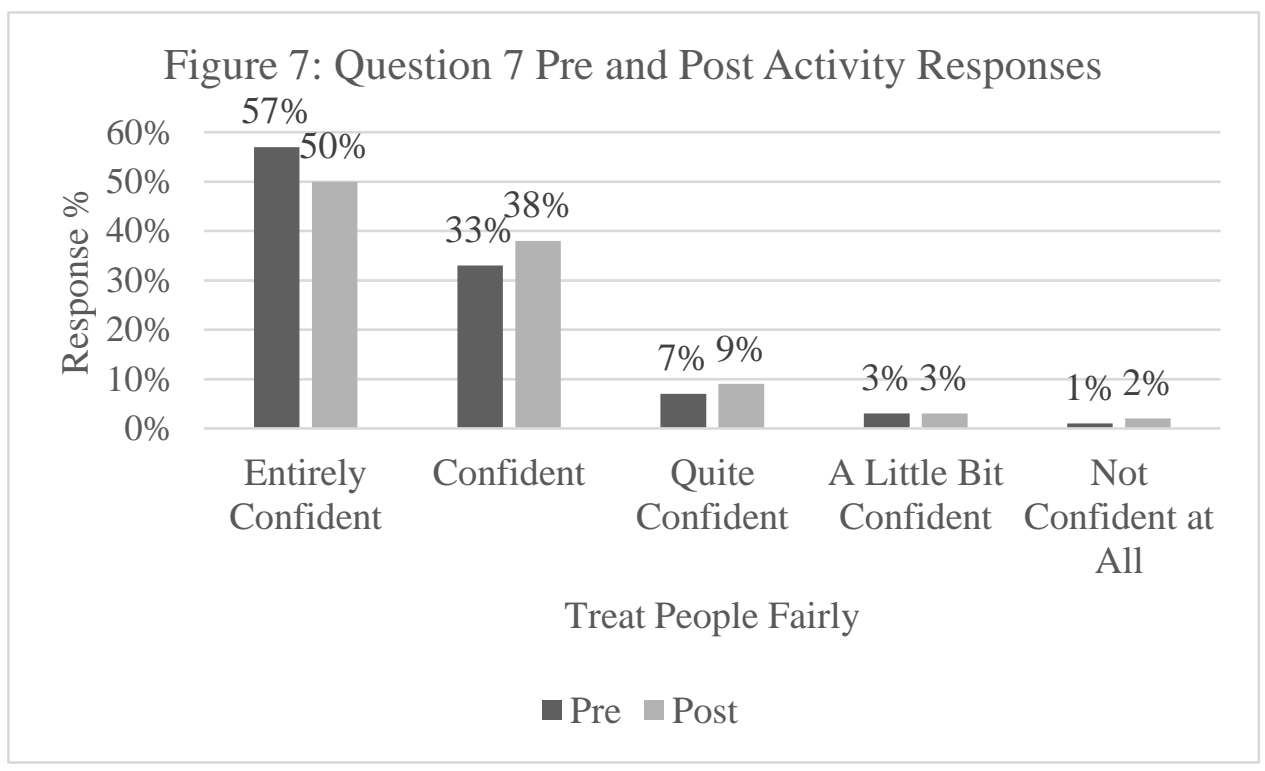

We appreciate that this question is asking students to project their "possible selves"69 onto their future career progression, but they had participated in a learning activity that asked them to role-play in a recruitment process. Therefore, the authors felt it gave the students the opportunity to think about their potential positioning within the complex graduate recruitment market, at least as students perceive that at this point in their lives.

${ }^{69}$ Hazel Markus and Paul Nurius, 'Possible Selves' (1986) 41(9) American Psychologist 954; Francis, 'Legal Education, Social Mobility and Employability: Possible Selves, Curriculum Intervention and the Role of Legal Work Experience' (n 17). 
Figure 7 shows that before the session, the vast majority of students had high confidence in their ability to treat others fairly, in the future: $90 \%$ of students being either confident or entirely confident. The post-activity responses were very similar to the preactivity responses. It is likely that the session had some effect, with some students moving from entirely confident, confident to quite confident. We found no outstanding differences between how different members of the cohorts answered this question, pre or post-activity. To the extent that the project sought to raise student awareness of the students' own biases, and how they might play out in future contexts, we can report only minimal success.

\section{Part 3: Findings from the focus group}

Through thematic analysis ${ }^{70}$ of the focus group transcript, the following key themes developed: increased awareness of diversity barriers; responses to diversity barriers motivations and frustrations; responses to diversity barriers - planning and strategy; individual responsibility to develop employability; and responsibility for reducing diversity barriers.

\section{Increased awareness of diversity barriers}

There seemed a consensus among the student participants that The Fairness Project learning activities had increased their awareness of the diversity barriers in the legal profession. This was generally perceived to be beneficial i.e. that they would rather know

\footnotetext{
${ }^{70}$ Described as a "method for identifying, analysing and reporting patterns (themes) within data" by Virginia Braun and Victoria Clarke, 'Using thematic analysis in psychology' (2006) 3(2) Qualitative Research in Psychology 77, 79.
} 
about the barriers, however challenging, than remain unaware:

To be honest - to be fair - the barriers, they need to be aware of [them] to be employable and market ready. You need to be aware of them to be market ready. Like I said earlier, the worst part would be to go into a job and not be aware of any possible barriers.

Comments from different participants indicated an understanding of the range of potential barriers that they may face (e.g.: poor A-level grades; accent; implications of which University they have studied at; socio-economic background; disability; gender etc.) and an appreciation that these could impact on their individual employability prospects. Francis posited that as legal educators, one of our challenges is to "develop critical readings of employability for our students and acknowledge the structural constraints in which opportunities are seized and lost". ${ }^{71}$ The comments would indicate that The Fairness Project addressed that challenge. This sense of an increased knowledge of barriers underpinned much of the ensuing discussions within the focus group, as demonstrated below.

\section{Responses to diversity barriers - motivations and frustrations}

The focus group discussions demonstrated that The Fairness Project learning sessions had provided an opportunity for students to self-reflect. Some of the participants described the feelings and attitudes engendered by this process of self-reflection, giving an insight into their motivations and frustrations. There was understandable disillusionment expressed by some participants as they explained their perceptions of diversity barriers, as personally experienced by them. For example, one participant

${ }^{71}$ Francis, 'Legal Education, Social Mobility and Employability: Possible Selves, Curriculum Intervention and the Role of Legal Work Experience' (n 17) 201. 
articulated her frustration with law firms when finding that her socio-economic background impeded her ability to access employment with them:

And they never appreciate the kind of work that you're put through to try and pull yourself out of, sort of, like that class, that you're trying to upgrade yourself. They don't appreciate how, like, the way you've grown up is not the way you want to be... or the way you're... trying to grow. They never seem to appreciate that. There are some people who are ready, who are from a higher class, and they go for them. ${ }^{72}$

The last sentence of this quotation also reveals an issue highlighted as particularly unfair by other participants: the recognition of the advantages that social capital offers ${ }^{73}$ to more well-connected applicants seeking to enter the profession: "a lot of it comes down to who you know rather than what you know, and I've found that to be very realistic". ${ }^{74}$

Nonetheless, it is interesting that despite knowledge of the barriers, many remained positive about their future, views shared by participants in Sommerlad's 2007 study. ${ }^{75}$ Several participants articulated determination and a "growth mindset"

72 This is certainly the case in elite firms as seen in Ashley and Empson, 'Differentiation and Discrimination: Understanding Social Class and Social Exclusion in Leading Law Firms' (n 4).

${ }^{73}$ Bourdieu (n 14); Rolfe and Anderson (n 4).

${ }^{74}$ Andrew Francis' findings that students with family or friend "connections" were more likely to secure early legal work experience support this perspective: Francis, 'Legal Education, Social Mobility and Employability: Possible Selves, Curriculum Intervention and the Role of Legal Work Experience' (n 17) 187-188; Mel Fugate, Angelo Kinicki and Blake Ashforth identify social capital (defined as "the goodwill inherent in social networks") as integral to one of their dimensions of employability: Mel Fugate, Angelo J Kinicki and Blake E Ashforth, 'Employability: A psycho-social construct, its dimensions, and applications' (2004) 65(1) Journal of Vocational Behavior 14, 23-24.

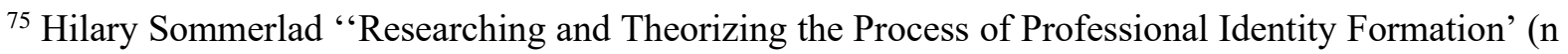
43) 202, although she reported on some students not being realistic about obstacles and aspirations.

${ }^{76}$ Carol Dweck uses the phrase "growth mindset" to describe individuals who respond to setbacks or failures with resilience and effort, believing that they can achieve more by trying harder. This contrasts with her description of individuals with a "fixed mindset" as those who perceive setbacks as a reflection 
approach to diversity barriers, perceiving them as a challenge to be tackled, rather than as an immovable impediment:

It motivated me a lot more, to push a lot more hard, and try and push through those barriers.... So yeah, I'm sort of like striving a lot more now.

Self-perceptions of confidence in overcoming employability challenges can be valuable in their own right, in sustaining motivation when barriers are encountered. ${ }^{77}$

\section{Responses to diversity barriers - planning and strategy}

One of the themes arising from the focus group was how most participants had been motivated by their The Fairness Project learning to plan and act upon strategies to develop their own employability. ${ }^{78}$ Increased awareness of diversity barriers seems to have precipitated reflections around their individual backgrounds; strengths and weaknesses; and hopes and aspirations, such that they became intentionally more strategic in their career planning. ${ }^{79}$ Participant examples of planning and action included:

of their own "fixed" limitations and respond by giving up: Carol S Dweck, Mindset: The New Psychology of Success (Random House 2006).

${ }^{77}$ More generally, Roland Benabou and Jean Tirole emphasise the benefits of self-confidence in overcoming setbacks: Roland Benabou and Jean Tirole, 'Self-confidence and personal motivation' (2002) 117(3) Quarterly Journal of Economics 871, 877. See also Dacre Pool and Sewell (n 10).

${ }^{78}$ To some extent, participants' contributions reflected elements of Kolb's learning cycle as they used their learning from The Fairness Project, incorporating their understanding of the legal market and their prospects within it (abstract conceptualisation) to plan new strategies to position themselves more favourably (active experimentation); and then take action to progress these plans (concrete experience): DA Kolb, Experiential Learning: Experience as the Source of Learning and Development (Prentice Hall, 1984).

${ }^{79}$ Hilary Sommerlad and others, reported that this type of strategic planning did not usually occur at this early stage: Sommerlad and others, 'Diversity in the Legal Profession in England and Wales: A Qualitative Study of Barriers and Individual Choices' (n 4) 59. 
applying early for LLM Law courses; applying to transfer to London for the next academic stage of training to maximise the opportunities of securing a London-based training contract; and changing CVs to be more honest about poor A-level results (rather than trying to hide them) while mitigating this with other strengths and more current experience and qualifications. A particular sub-theme that developed was participants who had increased their extra-curricular activities to build their CVs following the learning sessions, demonstrating an increased awareness of the need to add value and gain a positional advantage in the labour market: ${ }^{80}$

I feel like I'm doing a lot... I'm doing the arbitration course and I'm awaiting results on that. I've done, as has X, the debating at the prison. These guys have done mediation, whether they're being modest and say it or not. They've done the competitions and stuff. But I think I know a lot of people who've gone out and done a lot more.

Some participants had actively developed their professional networks to build social capital. ${ }^{81}$ Examples included visiting chambers; attending guest speaker events and Law Fairs; and speaking to prospective employers. By engaging in these opportunities, participants, particularly those with no access through family or friends to the legal sector, showed how they were developing a better understanding of the legal profession and their potential future within it.

${ }^{80}$ Michael Tomlinson, “"The Degree is not enough": students' perceptions of the role of higher education credentials for graduate work and employability' (2008) 29(1) British Journal of Sociology of Education 49, 58. See also Ann-Marie Bathmaker, Nicola Ingram and Richard Waller, 'Higher education, social class and the mobilisation of capitals: recognising and playing the game' (2013) 34(56) British Journal of Sociology of Education 723, which examines the middle-class advantage in developing capitals, including generating capitals through extra-curricular activities.

${ }^{81}$ See Francis, 'Legal Education, Social Mobility and Employability: Possible Selves, Curriculum Intervention and the Role of Legal Work Experience' (n 17). 
There was also a sense that some participants were making more targeted choices in selecting which legal employers to apply to. One participant reflected on how her approach had changed following The Fairness Project sessions:

There's stuff I know, because that's how I've been brought up, but there's other stuff that I didn't know, but now I do, it's gonna change my view on who I apply to.

Another participant said that she would focus her efforts on applications that might offer a higher chance of success:

But what I've been taught through the classes is not to go for stuff that's out of your reach but understand what's there in front of you. Some firms, I know I've got a good chance.

Rowan and Vaughan refer to this as "opting out", where some students perceive there is no "fit" between them and the culture of certain law firms and do not therefore apply to those firms. ${ }^{82}$ The students are being strategic in terms of which firms to target and not applying where they do not expect to be successful. ${ }^{83}$

\section{Individual responsibility to develop employability}

Following on from this discussion of participants' planning and action, a further theme developed: whose responsibility should it be to develop student employability? There was a sense that responsibility to maximise employment opportunities lay firmly with students, and not merely with staff. The quotation below is an example of the forthright

\footnotetext{
${ }^{82}$ Rowan and Vaughan, "Fitting in" and "opting out": exploring how law students self-select law firm employers' (n 4).

${ }^{83}$ An argument advanced by elite law firms is that lack of diversity amongst their trainees was not because of their recruitment practices but because of who chose to apply. This was discussed by Rolfe and Anderson, who questioned whether students were not applying because they thought they would not succeed, and this would appear to be the case here: Rolfe and Anderson (n 4) 332.
} 
views expressed by some of the participants, linking proactive behaviour and employability: ${ }^{84}$

You guys can put all the opportunities there, you can show us what to do to get a good degree, but at the end of the day, it's up to us doing it, to take advantage of it and actually do it. If a student doesn't do it, it will show up in later life. That may sound quite harsh, but I fully believe that if they don't want to get involved at University, that is their choice. And if they do well, they do well and good luck to them. But if they don't do as well as somebody else, they've only got themselves to blame.

\section{Responsibility for reducing diversity barriers}

Some participants expressed disgruntlement with the current extent of diversity barriers and suggested that the profession should take more responsibility for addressing this. One participant explained her frustrations with the barriers that she faced in securing a training contract due to her socio-economic background, gender and ethnicity. Despite her best efforts to study hard and to make the most of employability opportunities provided by the University, she felt that the profession was not attempting to meet her halfway.

You go to law firms, it's as though you're on a totally different like, completely different ends of the field. And university does come some way to stretch you to the other side, but they [the law firms] don't do enough to reach us.

This perspective seems justified in light of the profession's resistance to diversity progress as documented earlier. ${ }^{85}$

\footnotetext{
${ }^{84}$ Mel Fugate and others assert that behaving proactively "enhanced one's ability to identify and realise career opportunities": Fugate, Kinicki and Ashforth (n 74) 21.

85 This participant's perspective seems justified when considering the profession's resistance to diversity progress, see Sommerlad and others, 'Diversity in the Legal Profession in England and Wales: A Qualitative Study of Barriers and Individual Choices' (n 4).
} 
Other participants presented a more positive outlook, envisaging their own potential as change makers once within the profession. These participants tended to be those who were most confident of overcoming the diversity barriers in accessing the profession themselves: ${ }^{86}$

With our generation, it will soon change. As soon as we get into jobs and as soon as we work our way up, we will be the effective body that does eventually change things.

Such perspectives may seem a little naïve, when considering the level of entrenchment of barriers. ${ }^{87}$ However, there was only a small minority of participants who expressed reservations about their power to instigate progress:

I don't know that it will change. I don't think this kind of thing [The Fairness Project] is widespread enough to change that. I don't think your generation [McKee and Nir were both in legal practice in the 1990s] would have set about to put in these barriers, yet they are still there. I don't think it will be fast or easy to remove them, but this can only help.

\section{Evaluation of The Fairness Project}

As part of the focus group and at the end of the questionnaires, we asked participants for their views on The Fairness Project learning activities, and what suggestions they might make for improving them for future cohorts. The overwhelming view was that the

\footnotetext{
${ }^{86}$ Bandura states that "The higher the level of people's perceived self-efficacy the wider the range of career options they seriously consider, the greater their interest in them, and the better they prepare themselves educationally for the occupational pursuits they choose and the greater is their success": A Bandura, 'Self-efficacy' in VS Ramachandran (ed), Encyclopedia of Human Behavior (Vol 4, Academic Press 1994) 7.

${ }^{87}$ Sommerlad suggests that diversification in the profession's supply side has "generated new modes of gendered and classed differentiation and division which excludes outsiders", Sommerlad, 'Researching and Theorizing the Process of Professional Identity Formation' (n 43) 217.
} 
learning activities had served a valuable purpose in raising the issue of diversity barriers and in offering students an opportunity to consider how they could respond to any such barriers that they may face. In the focus group, there was a detailed discussion on when would be the optimum time for students to undertake these learning sessions but no consensus was established. Some students thought that year three was the ideal time as it provided information and thinking space "just in time", meaning that participants were ready, able and motivated to plan and to take concrete action when there was a real time imperative to do so. Others felt that earlier in the course would be better, so that students would have more opportunities to take part in extra-curricular activities and to build up their skills and experiences over a longer period. Those who wanted to do work placements in bigger firms were particularly interested in seeing the learning sessions occur sooner, so that students had a better understanding of the legal landscape, and time to build their CVs to maximise their chances of securing such a placement.

Other suggestions made by students included using more role play activities; using case studies that reflected a broader range of student backgrounds and characteristics; linking the learning sessions more explicitly to broader career development and employability initiatives; and offering drop-in sessions for one to one support on devising tailored strategies.

\section{Discussion}

Our data on The Fairness Project suggests some success with some of our intended objectives, but more limited success with others. Our motivation is to build on the existing literature on (lack of) equality and diversity in the legal profession and its impact on employability, not by further reporting its existence and effects, but by seeking to secure positive change, however small, and reporting on that intervention. Further reflection 
offers the following insights.

In terms of the first objective - raising student awareness of diversity barriers to entry into, and progression within, the legal profession - we observed a positive effect. Following the learning activities, over $80 \%$ of students felt they were at least "well aware" of diversity barriers on entry to (with almost $75 \%$ at least "well aware" of barriers on progression through) the legal profession. This encouraging data reflects a substantial shift from the baseline position before the learning activities. Data from all three law schools showed an increase in awareness, with Sheffield students claiming the highest level of awareness at the outset. This is perhaps unsurprising, given the higher proportion of privately educated students at Sheffield who may have easier access through family and friend networks to insights into the legal profession. ${ }^{88}$ The learning activities seem to have been most effective in UCLan, and then in Northumbria, in terms of stronger shifts in awareness following the learning activities. This may be due to the format of the learning activity delivery. UCLan and Northumbria used small workshop-based groups throughout (circa 12-18 participants in each), which may be more conducive to in-depth exploration of the difficult issues discussed than the larger café-style whole cohort structure in Sheffield ${ }^{89}$ BAME students had a higher awareness than white students, both

${ }^{88}$ The advantage of personal contacts is discussed, inter alia, in Rolfe and Anderson (n 4) 319. In Lindsey Macmillan, Claire Tyler and Anna Vignoles, 'Who gets the top jobs? The role of family and background and networks in recent graduates' access to high-status professions' (2015) 44(3) Jnl Soc. Pol 487, the authors found that privately educated graduates are a third more likely to enter into highstatus occupations (such as law) than state educated graduates. Social networks were also found to provide an additional advantage.

${ }^{89}$ Workshop teaching encourages "active" learning where learners have a more protagonistic, less passive role: Liam Kane, 'Educators, Learners and Active Learning Methodologies' (2004) 23(3) International Journal of Lifelong Education 275; David Mills and Patrick Alexander, 'Small Group Teaching: A Toolkit for Learning' (The Higher Education Academy, 2013). 
before and after the learning activities (with both groups increasing their awareness through the activities), but white students had a bigger shift in their awareness. This may suggest that the project has particular benefit for white students in terms of raising awareness, perhaps, of some aspects of their own "white privilege". ${ }^{90}$ While law students from white backgrounds are less likely to be subject to diversity barriers in the profession than law students from BAME backgrounds because of race, it is important to raise the awareness of all who may otherwise perpetuate the "status quo" of structural racism. ${ }^{91}$ Although raising awareness of the existence of diversity barriers within the profession is by far the easiest of the three objectives for us to achieve, we recognise that the inherent time constraints within The Fairness Project learning sessions limited opportunities for a more detailed exploration of the structural inequalities in the profession, and the complex historic and social factors involved.

${ }^{90}$ The concept of "white privilege" relates to the structural advantages that white people experience in comparison with the disadvantages experienced by those from BAME backgrounds. McIntosh states, in her seminal work on white privilege: "White privilege is like an invisible weightless knapsack of special provisions, maps, passports, codebooks, visas, clothes, tools, and blank checks". Peggy McIntosh, 'White privilege: Unpacking the invisible knapsack' (Wellesley College, 1989), 1 <https://nationalseedproject.org/images/documents/Knapsack_plus_Notes-Peggy_McIntosh.pdf> accessed 25 March 2020. Bhopal suggests that "whites overtly use their white identity as a form of privilege and entitlement - particularly in relation to competition for jobs and prestige". Kalwant Bhopal, White Privilege: The Myth of a Post-Racial Society (Policy Press University of Bristol 2018) 24.

${ }^{91}$ Eddo-Lodge refers to "structural racism" as being "dozens, or hundreds, or thousands of people with the same biases joining together to make up one organisation, and acting accordingly", Reni EddoLodge, Why I'm no longer talking to white people about race (Bloomsbury Publishing 2017), 64. 
Raising awareness of such diversity barriers is potentially sensitive for some law students, particularly those experiencing intersectionality of social identities, ${ }^{92}$ who may recognise for the first time the reality of unfair diversity barriers in the career to which they aspire. Though difficult, we feel it is an essential first step. There are challenges associated with exploring equality and diversity in course content and of effectively managing potentially difficult conversations about structural barriers. ${ }^{93}$ However, if we, as educators, are not prepared to engage our students with honesty, values and pragmatism, who else will do so ${ }^{94}$ It has been suggested that this period of early adulthood is the optimum time for the formation of a personal and social identity. ${ }^{95}$ It is

${ }^{92}$ Those with intersecting social identities, each of which may be associated with disadvantage, may find themselves particularly marginalised, Crenshaw (n 32); Sommerlad and others, 'Diversity in the Legal Profession in England and Wales: A Qualitative Study of Barriers and Individual Choices' (n 4).

${ }^{93}$ See, for instance: Joy Gaston Gayles and others, 'Faculty Teaching Diversity Through Difficult Dialogues: Stories of Challenges and Success' (2015) 52(3) Journal of Student Affairs Research and Practice 300. Gayles and others report on the findings from a study of faculty staff who create specific learning environments for difficult conversations about diversity issues.

${ }^{94}$ Jon Nixon argues that "to be a good academic one has to go on learning about what it means to be accurate and sincere, attentive and honest, and courageous and compassionate": Jon Nixon, 'Excellence and the Good Society' in Alan Skelton (ed), International Perspectives on Teaching Excellence in Higher Education: Improving Knowledge and Practice (Routledge 2007) 20. Marian Fitzmaurice's findings demonstrate that HE lecturers perceive values and morality as core to their practice: "a view of professionalism is emerging which acknowledges the complex and difficult nature of teaching in higher education, the importance of values and professional morality and the merit of constantly striving to improve practice through reflection": Marian Fitzmaurice, "Voices from within: teaching in higher education as a moral practice' (2008) 13(3) Teaching in Higher Education, 341, 349-50.

${ }^{95}$ Erikson argued that late adolescence and early adulthood are unique and ideal times for the formation of a personal and social identity. Erikson's theory explored the idea of identity developing best when young people are given a psychosocial moratorium, a time and a place when they can experiment. Erik Erikson, 'Ego Development and Historical Change' (1946) 2 The Psychoanalytical Study of the Child 359; Erik Erikson, 'The Problem of Ego Identity' (1956) 4(1) Journal of American Psychoanalytic 
therefore an appropriate time to experience a confrontation with "diversity and complexity, lest young people passively make commitments based on their past experiences, rather than actively think and make decisions informed by new and more complex perspectives and relationships". ${ }^{96}$ Like Gurin, we think that universities are uniquely well-placed to provide an opportunity to support young adults through this identity development stage and we suggest that their perspectives on equality and diversity, particularly in the context of their chosen profession, should be challenged during this period. Therefore, it is our belief that law schools should encourage students to challenge their own perceptions and biases during this identity development phase.

To mitigate the potential harshness of the message, we encouraged ownership of the learning by students. Rather than presenting statistics "lecturer-to-student", we prompted students to discover for themselves the realities of the lack of diversity and inclusion in the legal profession. ${ }^{97}$ Our experience of facilitating this process was that while many students felt disillusioned, the prevailing emotions were shock and outrage. ${ }^{98}$

Association 56. Gurin and others argue that this "moratorium" should include a time and a place where young people can experiment with different roles and ways of thinking before making a permanent commitment to occupations, relationships, political ideas and a philosophy of life. Patricia Gurin and others, 'Diversity and Higher Education: Theory and Impact on Educational Outcomes' (2002) 72(3) Harvard Educational Review 330, 334.

${ }^{96}$ Gurin and others, (n 95) 334.

${ }^{97}$ Our pedagogical approach was informed by Bloom's classification of learning objectives and was mainly positioned in the affective domain, which concerns feelings, attitudes, values and motivations: Krathwohl, Bloom, and Masia, Taxonomy of Educational Objectives, The Classification of Educational Goals. Handbook II: Affective Domain (n 47).

${ }^{98}$ Although negative emotions such as anger are often perceived to have a detrimental effect on learning, Anna Rowe and Julie Fitness' findings show that lecturers recognise "the potential usefulness of emotions such as anger and frustration in motivating students to engage in a deeper way with their learning": Anna Rowe and Julie Fitness, 'Understanding the Role of Negative Emotions in Adult Learning and Achievement: A Social Functional Perspective' (2018) 8 Behavioral Sciences 27, 8. 
However, there was a collegiate and supportive element to the learning activities that, for many students, engendered a sense of cohort solidarity that unfair access to the profession should be challenged. ${ }^{99}$

The focus group gave the participants an opportunity to explore the perceived barriers in more detail and our findings suggest that raising student awareness of the issues gave students the opportunity to use that new knowledge to positive effect and reflect on the issues at a deeper level. ${ }^{100}$

We recognise that The Fairness Project's second objective, equipping students to navigate diversity barriers in the profession, is more challenging than the first to achieve. It takes time, reflection and planning for any student to develop their own tailored strategies to navigate their way effectively into the careers to which they aspire. ${ }^{101}$ Sometimes, for some of them, the structural barriers will prove insurmountable. ${ }^{102}$ Many of our students have already decided to pursue a legal career. Others will have different plans, and many (particularly the year 1 students at Northumbria) will be at the very early stages of thinking about career possibilities.

99 This reflects the deeper levels of Bloom's affective domain, as students move from "receiving" and "responding to" information, towards "valuing" i.e. through internalising values, sometimes to the point of commitment: Krathwohl, Bloom, and Masia, Taxonomy of Educational Objectives, The Classification of Educational Goals. Handbook II: Affective Domain (n 47).

${ }^{100}$ The focus group findings of an increased awareness of diversity barriers reinforce the questionnaire findings in this context, see Parker and Tritter (n 58) 25.

${ }^{101}$ See Tomlinson, 'Investing in the self: structure, agency and identity in graduates' employability' (n 16); Fugate, Kinicki and Ashforth (n 74).

${ }^{102}$ See Rolfe and Anderson (n 4); Sutherland (n 4); Sommerlad and others, 'Diversity in the Legal Profession in England and Wales: A Qualitative Study of Barriers and Individual Choices' (n 4); Lehmann (n 4); Ashley and Empson, 'Differentiation and Discrimination: Understanding Social Class and Social Exclusion in Leading Law Firms' (n 4). 
Our findings suggest that The Fairness Project provided a focus and catalyst for students in the processes of self-reflection and planning. The pre- and post-activity questionnaires demonstrated a significant shift in the percentage of students who felt that they were at least "quite well equipped" to navigate their own career diversity barriers from $44 \%$ pre-activity to $74 \%$ post-activity. In terms of benefits for particular groups of students, the learning activities had more impact on building confidence in tackling diversity barriers for women; and state school educated students. This is encouraging as statistics show that both these groups are more likely to encounter diversity barriers in the legal profession, than their male and/or privately educated counterparts. ${ }^{103}$ The Fairness Project is of course placed within the broader context of the ongoing career and employability initiatives in each of the three law schools. Once again, the focus group findings provided corroboration of the questionnaire results, offering fuller insights into the ways in which participants had used their learning to become more strategic at this early stage in their career planning. ${ }^{104}$ We acknowledge that the true test of whether The Fairness Project has had an impact on this second objective cannot be measured definitively at this stage. What students think immediately after the learning sessions (or five months later in the case of focus group participants) may well fade over time. A

${ }^{103}$ Recent SRA diversity data shows that although $49 \%$ of lawyers in law firms are women, only $34 \%$ of partners are women; and that $21 \%$ of lawyers, and $23 \%$ of partners attended a fee-paying school (compared with 7\% in the general population): SRA, 'How diverse is the legal profession?' (n 22). See Ashley and Empson, 'Differentiation and Discrimination: Understanding Social Class and Social Exclusion in Leading Law Firms' (n 4) for a discussion of why leading law firms discriminate on the basis of social class.

${ }^{104}$ Hilary Sommerlad and others reported that this type of strategic planning did not usually occur at this early stage: Sommerlad and others, 'Diversity in the Legal Profession in England and Wales: A Qualitative Study of Barriers and Individual Choices' (n 4) 59. 
longer-term study exploring the career journeys of our respective cohorts would be beneficial here. It is also impossible to attribute all the career planning strategies described by focus group participants to The Fairness Project intervention. Some of them may have developed such strategies in any event, independently of the project.

A further consideration is that the focus group findings suggest that students' understandings of the solutions to diversity barriers lie more at the level of changing the behaviours of individuals (particularly themselves) rather than influencing systemic change. To this extent, this aspect of The Fairness Project enjoyed only limited success: students' understandings of structurally determined (lack of) equality and diversity in the legal profession develop, but students do not see the solutions to that problem in structural change. ${ }^{105}$ It would seem that the encoding of "merit" as individually determined is more embedded than we were able to successfully tackle with The Fairness Project. ${ }^{106}$

The third objective of The Fairness Project is by far the most demanding: to raise awareness of, and to challenge, any biases that the students have themselves, in the hope that this will empower them to become fairer employers in the future. It is sensitive and

\footnotetext{
${ }^{105}$ Louise Morley posits that "Graduate recruitment can be a relay of power in so far as it reproduces social privilege and domination. Employability, while it is a key policy term, is not a neutral concept. It is another way of creating social differentiation in a mass market of graduates." Morley (n 6) 88; Louise Ashley and others suggest that the current focus on individual responsibility for improving social mobility "neglects the 'demand side' causes of limited diversity, including the role played by current definitions of 'talent'. Unless elite firms further interrogate their own notions of talent, it is likely that those who participate in access schemes will continue to face barriers to entry and progression": Ashley and others, 'A Qualitative Evaluation of Non-Educational Barriers to the Elite Professions' (n 31), 13.

${ }^{106}$ See Sommerlad, 'The "Social Magic" of Merit: Diversity, Equity and Inclusion in the English and Welsh Legal Profession’ (n 48) 2346-7.
} 
difficult for anyone to explore their own intrinsic value-systems and motivations, and to consider the extent of their biases, whether conscious or unconscious. ${ }^{107}$ It is therefore challenging to attempt this with students, particularly within the time constraints of The Fairness Project. We are working in Bloom's affective learning domain, seeking to move students through the five hierarchical "phases" to "characterisation", where individuals explore and develop their own value systems and behaviours. ${ }^{108}$ It is encouraging that our findings indicate even a modest increase in student awareness of their own biases, including a willingness to acknowledge unconscious biases. However, the findings on participants' recognition and acknowledgement of their own biases were underwhelming. This probably illustrates how problematic it was for the participants to understand these issues properly, let alone make progress in addressing their own biases. We do therefore acknowledge that the concepts in survey questions four to seven were complex and it is likely that there was a lack of shared understanding over terminology amongst the participants. As with the second objective of the project, it is impossible to know at this stage whether the learning activities will continue to have traction with students into the future, and whether they will embed principles of equity, diversity and inclusion into their own value systems, such that they can challenge effectively unfairness in the legal profession (or wherever their careers take them).

\footnotetext{
${ }^{107}$ Anthony G Greenwald and Mahzarin R Banjai, 'Implicit Social Cognition: Attitudes, Self-Esteem and Stereotypes' (1995) 102(1) Psychological Review 4; Pronin, Lin and Ross (n 67).

108 Krathwohl, Bloom, and Masia, Taxonomy of Educational Objectives, The Classification of Educational Goals. Handbook II: Affective Domain (n 47).
} 


\section{Conclusion}

The objectives of The Fairness Project are to raise student awareness of diversity barriers within the legal profession; to equip students to find their own possible ways through such barriers; and to encourage students to reflect on their own values and biases, so that they develop into fair employers in the future.

The results of this evaluation demonstrate that we have been effective to a reasonable extent in achieving our first objective, with our diverse student cohorts recognising the increase in their awareness of the barriers that they may well face when seeking graduate legal employment. Despite the potential for crushing students' career aspirations that awareness of such barriers might engender, our evidence shows that The Fairness Project also met our second objective to some extent: it had a positive influence in increasing student perceptions of how well they could address these challenges. Students felt more equipped to find a way through the barriers, with some demonstrating self-reflection, determination and strategic planning in response to their learning. We wanted students to develop an understanding that employability should be seen as a "socially active process by the way graduates position themselves and are positioned" 109 As the evaluation suggests, The Fairness Project was more successful in evoking practical responses at an individual level than in understanding and tackling lack of diversity and equality in the legal profession at a systemic level. With respect to the third objective, the findings were much less conclusive. Students demonstrated a small improvement in awareness of individual bias following the learning sessions, with only a few articulating aspirations to change the profession from within, to make it fairer in the

109 Michael Tomlinson, 'Investing in the self: structure, agency and identity in graduates' employability' (n 16) 74. 
future. Tracking the career trajectories of our students is beyond the scope of our project, so we are unable to ascertain the extent to which the learning from The Fairness Project continues to have an influence.

As legal educators, we seek to teach our students with robust, but compassionate pragmatism. We consider it a responsibility to engage in difficult conversations ${ }^{110}$ with them about the impact that their gender, ethnicity or socio-economic background might have on their individual career prospects. We hope to build up, not to crush student aspirations but recognise that the construction of professional identities and individual employability is complex and needs to be tempered by realism. ${ }^{111}$ We aim to stimulate our students to critique and develop their own value systems, ${ }^{112}$ such that they may choose to question and influence unfair recruitment practices and progression pathways in their future careers, whether legal or otherwise. We believe that The Fairness Project has supported these endeavours, to a greater or lesser extent.

The Fairness Project has potential benefits for law schools more widely across the UK, ${ }^{113}$ including, or perhaps especially, in the more traditionally elite universities. It

\footnotetext{
${ }^{110}$ Wing Sue and others (n 9) 1090.

${ }^{111}$ Markus and Nurius (n 69); Francis, 'Legal Education, Social Mobility and Employability: Possible Selves, Curriculum Intervention and the Role of Legal Work Experience' (n 17).

${ }^{112}$ Bloom's affective learning framework is a hierarchy of stages. In The Fairness Project sessions we seek to support students through the "receiving" and "responding to phenomena" stages to, at the very least, the "valuing" stage, where they internalise some of the values of equality and diversity. Some students will move beyond this towards the final "characterization" stage, where the values become part of their characters, such that they act in ways that reflect their internal commitment to such ideals. Krathwohl, Bloom, and Masia, Taxonomy of Educational Objectives, The Classification of Educational Goals. Handbook II: Affective Domain (n 47).

${ }^{113}$ The Fairness Project materials have already been shared on request with a range of other University Law Schools: Liverpool, Birmingham, Portsmouth, Wolverhampton, Middlesex and the OU.
} 
is as important to address professional diversity barriers with students from privileged backgrounds, as it is with those from disadvantaged backgrounds. ${ }^{114}$ The Fairness Project may also have traction in other jurisdictions where similar barriers exist. Other possible strands for development of the learning intervention is through adaptation of the material for other disciplines; and for more generic employability strands. ${ }^{115}$

We recognise the limitations of any one intervention or project to influence change when pressure from above, from government and the legal regulators, has had limited impact in addressing issues of diversity and social mobility. However, as educators, we should seek to support the lawyers of the future to develop their own value systems and knowledge bases so that they are able to challenge unfairness in the profession effectively while navigating successfully around the diversity barriers that they may face themselves. We passionately believe in equity and social justice and we believe, based on our findings, that the experience of The Fairness Project learning activities has, at least to some extent, encouraged our students to question the discriminatory recruitment practices that persist in the profession. We hope that, in some small way, we have helped some of them to be agents of change in the future. The Fairness Project can only ever play a small role in raising awareness of inequity in access to and progression within the legal profession, but we remain convinced that university is an important arena in which to do this. Above all, The Fairness Project is not about reporting on disadvantage: it is about seeking to do something to redress it.

\footnotetext{
${ }^{114}$ In some ways, one of the most important insights from the project, reported in McKee and others (n 45) 199 , is the opportunities it provides for fostering reflection and learning among white, male, privately-educated law students.

115 The Fairness Project materials have been requested for adaptation and use by Lancashire Business School at UCLan and by the Careers Service at Wolverhampton University and The Fairness Project authors are willing to share materials openly on request.
} 


\section{Acknowledgements}

We are grateful for the support of the University of Central Lancashire School of Law and Social Science, University of Northumbria Law School and University of Sheffield Law School (especially Robert Burrell) and for the excellent research assistance provided by Rachel Allsopp at Northumbria Law School. We would like to thank the journal editors and anonymous reviewers for their 'tough love' comments. We are also very grateful for the insights of the many students with whom we have shared this project and for the comments and suggestions made at the HEA Annual Conference, Manchester, 2017, the Society of Legal Scholars Annual Conference, Dublin, 2017 and the IJCLE Annual Conference, Monash University, Melbourne, 2018.

\section{Disclosure Statement}

No potential conflict of interest was reported by the authors. 